ORNL/M-3245

OAK RIDGE NATIONAL LABORATORY

MARTIN MARIETTA

\author{
An Archaeological \\ Reconnaissance and Evaluation \\ of the Oak Ridge National \\ Laboratory, Oak Ridge \\ Reservation, Anderson and \\ Roane Counties, Tennessee
}

Glyn D. DuVall

RECEIVE.

FEB 151994

OSTI

\section{MANAGED BY}

MARTIN MARIETTA ENERGY SYSTEMS, INC.

FOR THE UNITED STATES

DEPARTMENT OF ENERGY 


\title{
AN ARCHAEOLOGICAL RECONNAISSANCE AND EVALUATION OF THE OAK RIDGE NATIONAL LABORATORY, OAK RIDGE RESERVATION, ANDERSON AND ROANE COUNTIES, TENNESSEE
}

\author{
Prepared by \\ Glyn D. DuVall, Archaeologist \\ DuVall \& Associates, Inc. \\ Cultural Resources and Environmental Services \\ P.O. Box 150625 \\ Nashville, Tennessee \\ 37215-0625
}

December 1993

Finalized January 1994

Prepared for the

Oak Ridge National Laboratory

Oak Ridge, Tennessee 37831 managed by

Martin Marietta Energy Systems, Inc.

for the U. S. Department of Energy

under Contract No. DEAC05-84OR21400

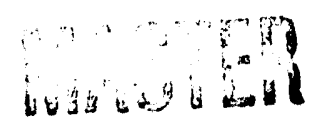




\section{TABLE OF CONTENTS}

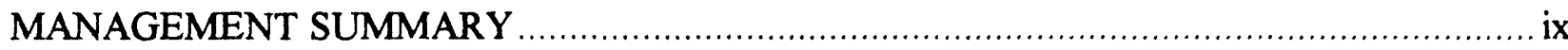

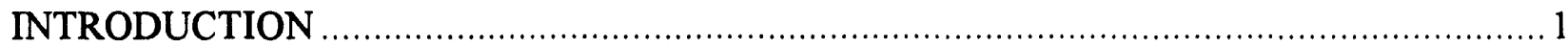

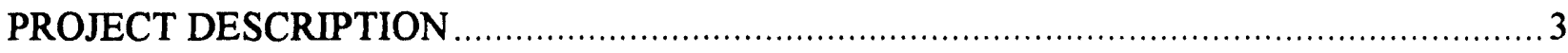

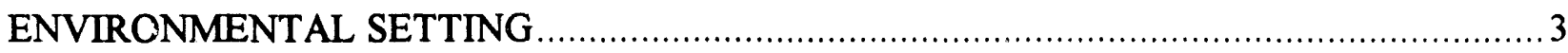

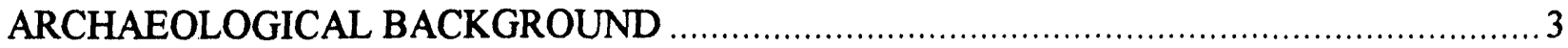

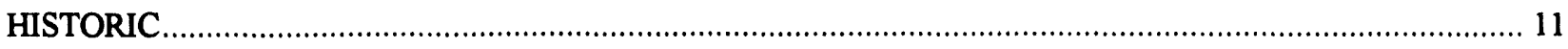

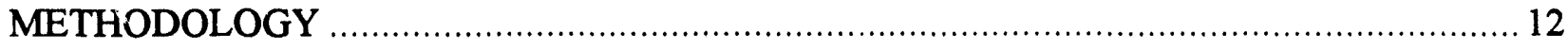

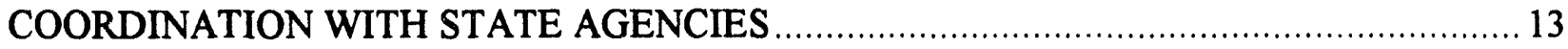

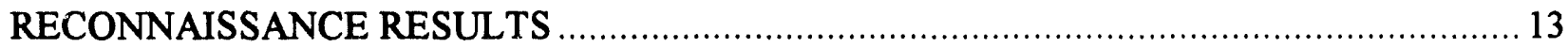

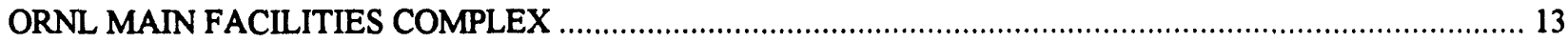

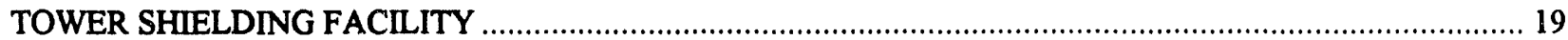

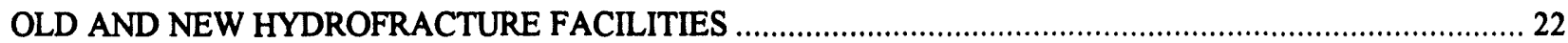

HIGH FLUX ISOTOPE REACTOR ¿XPERIMENT FACILITY AND AIRCRAFT REACTOR

EXPERIMENT FACILITYMMOLTEN SALT REACTOR EXPERIMENT FACILITY .................................... 22

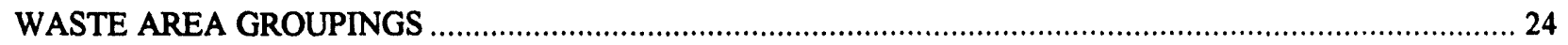

DOSIMETRY APPLICATIONS RESEARCH FACILITY AND HEALTH PHYSICS

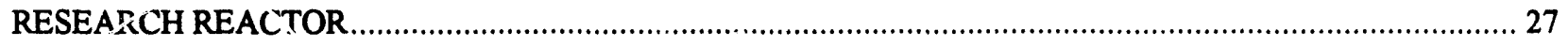

EXPERIMENTAL GAS-COOLED REACTOR FACILITY/ROBOTICS AND PROCESS

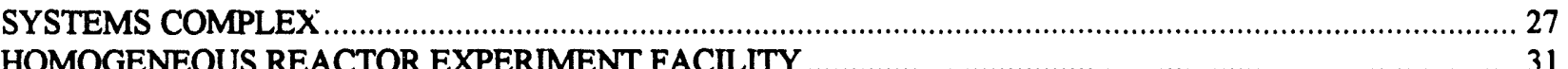

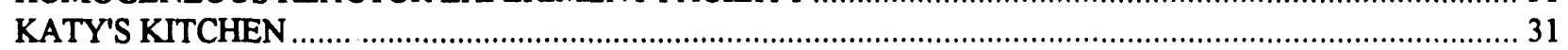

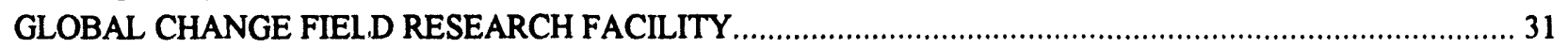

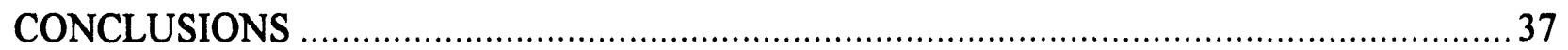

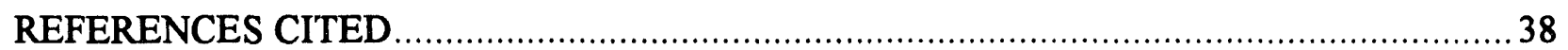

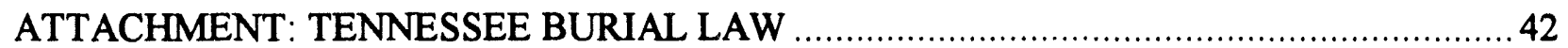




\section{LIST OF FIGURES}

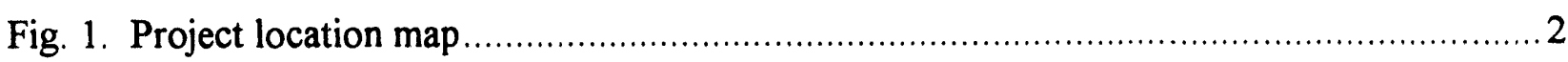

Fig. 2. Generalized physiographic map of Tennessee showing Anderson and Roane counties ...... 4

Fig. 3. Boundaries of previously surveyed areas at the Oak Ridge National Laboratory ............. 8

Fig. 4. Boundaries of the New Bethel Baptist Church and Cemetery ............................. 14

Fig. 5. Boundary of area surveyed as part of the Oak Ridge National Laboratory main facilities complex

Fig. 6. Boundary of area surveyed at the Tower Shielding Facility

Fig. 7. Boundaries of area surveyed at the Old and New Hydrofracture Facilities, High Flux Isotope Reactor Experiment Facility, and Aircraft Reactor Experiment Facility/Molten Salt Reactor Experiment Facility

Fig. 8. Location of Waste Area Groupings in and around the Oak Ridge National Laboratory main facilities complex

Fig. 9. Boundaries of areas surveyed at the Dosimetry Applications Research Facility, Health Physics Research Reactor, and associated water tank

Fig. 10. Boundary of area surveyed at the Experimental Gas-Cooled Reactor Facility/ Robotics and Process Systems Complex.

Fig. 11. Boundary of area surveyed at the Homogeneous Reactor Experiment Facility.

Fig. 12. Boundary of area surveyed at Katy's Kitchen . 33

Fig. 13. Boundary of area surveyed at the Global Change Field Research Facility 35 


\section{LIST OF PLATES}

Plate 1. Photograph of early construction phase at the Oak Ridge National Laboratory

Plate 2. Photograph of early construction phase at the Oak Ridge National Laboratory

Plate 3. 161-kV Substation, Building 0901, located due north of the Oak Ridge National Laboratory main facilities complex.

Plate 4. Oak Ridge National Laboratory Security Patrol Firing Range located northwest of the Oak Ridge National Laboratory main facilities complex.

Plate 5. Panoramic view of the Tower Shielding Facility ................................... 21

Plate 6. Typical view of a Waste Area Grouping ............................................ 26

Plate 7. View of Waste Area Grouping 6 with White Oak Lake (Waste Area Grouping 2) in foreground....

Plate 8. View of Dosimetry Applications Research Facility which is located in a restricted valley

Plate 9. View of Katy's Kitchen looking north 34

Plate 10. Panoramic view of the Global Change Field Research Facility 36 


\section{MANAGEMENT SUMMARY}

At the request of Martin Marietta Energy Systems, Inc., Oak Ridge, Tennessee, an archaeological reconnaissance and evaluation of the Oak Ridge National Laboratory (ORNL) developed areas was conducted between June 1 and September 2, 1993. The project was conducted by Glyn D. DuVall, Principal Investigator. ORNL project representative, Peter Souza, accompanied the principal investigator during all project evaluations.

The reconnaissance to assess adverse impacts to cultural resources located within the boundaries of federally licensed, permitted, funded or assisted projects was conducted in compliance with the National Historic Preservation Act of 1966 (Public Law 89-665; 16 USC 470; 80 Stat. 915), National Environmental Policy Act of 1969 (Public Law 91-190; 91 Stat. 852; 42 USC 4321-4347) and Executive Order 11593 (May 13, 1971).

Based upon the reconnaissance, a search of the site files at the Tennessee Division of Archaeology and a search of the National Register of Historic Places, the proposed construction on the site will have no impact on any property included in or eligible for inclusion in the National Register of Historic Places pursuant to 36 CFR 60.4. This judgement is based on the amount of prior disturbance associated with ORNL during the past 50 years.

Construction in the vicinity of the New Bethel Baptist Church and Cemetery should allow sufficient buffer to avoid direct and visual impact to the property. The determination of sufficient buffer area, either distance or vegetative, should be coordinated with the Tennessee Historical Commission, Office of the State Historic Preservation Officer. 


\section{AN ARCHAEOLOGICAL RECONNAISSANCE AND EVALUATION OF THE OAK RIDGE NATIONAL LABORATORY, OAK RIDGE RESERVATION, ANDERSON AND ROANE COUNTIES, TENNESSEE}

\section{INTRODUCTION}

At the request of Martin Marietta Energy Systems, Inc., Oak Ridge, Tennessee, an archaeological reconnaissance and evaluation of the Oak Ridge National Laboratory (ORNL) developed areas was conducted between June 1 and September 2, 1993. The project was conducted by Glyn D. DuVall, Principal Investigator. ORNL project representative, Peter Souza, accompanied the principal investigator during all project evaluations.

The purpose of the project was to conduct a reconnaissance survey and review of historical and archaeological sites within and immediately adjacent to ORNL developed areas. The reconnaissance and evaluation was designed to identify and map-locate prior areas of disturbance and their relationship to known or previously unidentified archaeological sites within the developed areas of ORNL. This action would identify areas that would not require additional archaeological investigations in the event that those areas should be selected as potential construction or waste disposal/treatment sites.

The reconnaissance to assess adverse impacts to cultural resources located within the boundaries of federally licensed, permitted, funded or assisted projects was conducted in compliance with the National Historic Preservation Act of 1966 (Public Law 89-665; 16 USC 470; 80 Stat. 915), National Environmental Policy Act of 1969 (Public Law 91-190; 91 Stat. 852; 42 USC 4321-4347) and Executive Order 11593 (May 13, 1971).

The location of the approximately 37,000-acre Oak Ridge Reservation (ORR) is divided between Anderson and Roane counties, with Roane County containing the largest percentage (@ $65 \%$ ) of the total area (Fig. 1). Due to the overall size of the study area and the fact that the majority of the archaeological and historical studies conducted in the counties have focused on the ORR, the major focus of the background and literature discussions will involve only those related to the ORR proper.

The following pages present the general environmental background, archaeological data, a description and evaluation of the reconnaissance findings, and a summary with recommendations for additional archaeological considerations. 


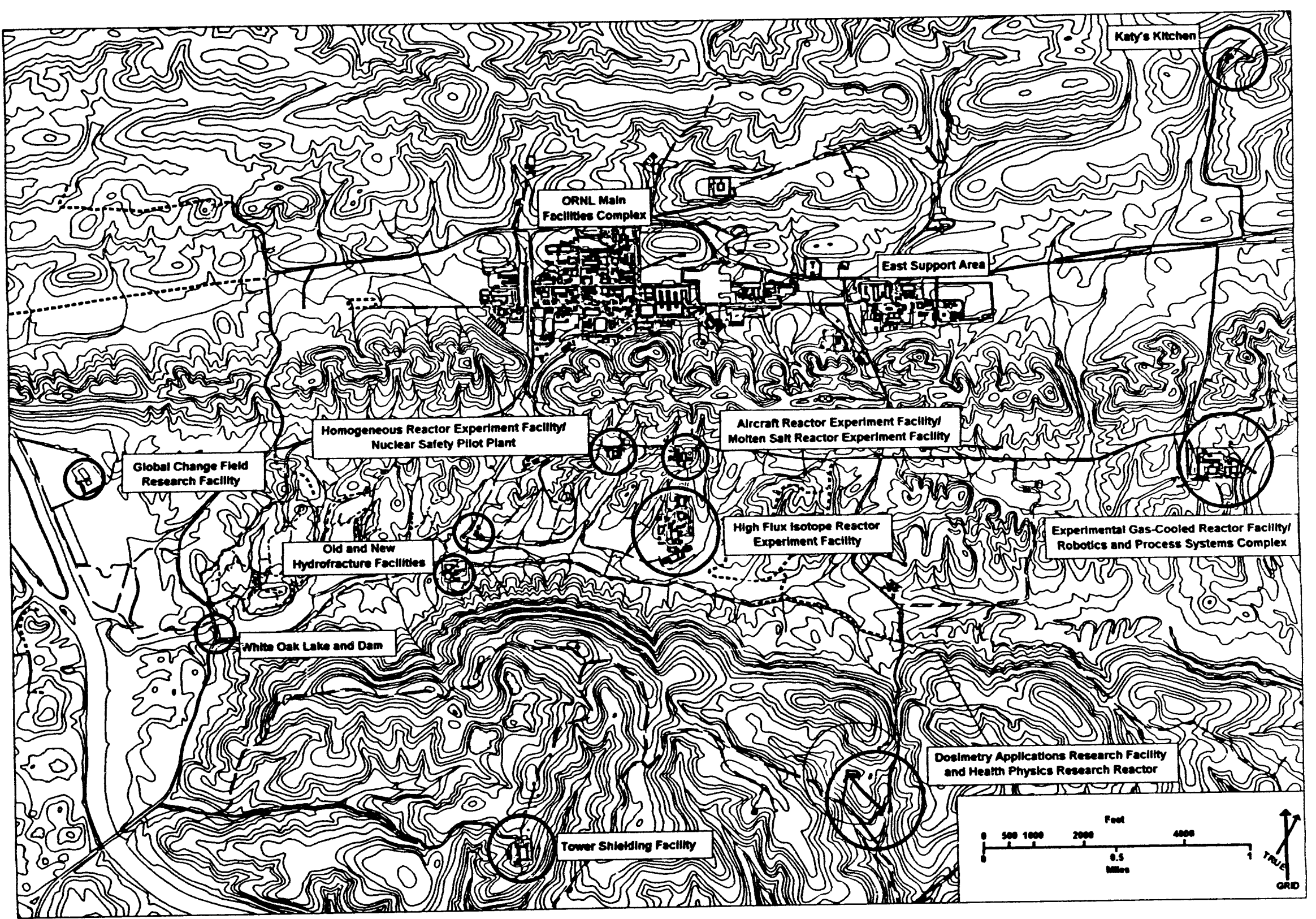

Fig. 1. Project location map. 


\section{PROJECT DESCRIPTION}

The project and survey area included all of the ORNL developed areas and areas immediately adjacent to developed areas. Included were ORNL facilities located at the (1) ORNL main facilities complex in Bethel Valley; (2) Tower Shielding Facility; (3) Dosimetry Applications Research Facility and Health Physics Research Reactor Facility; (4) High Flux Isotope Reactor Experiment Facility; (5) Old and New Hydrofracture Facilities; (6) Hazardous Waste Management Area; (7) Experimental Gas-Cooled Reactor Facility, now referred to as the Robotics and Process Systems Complex; (8) Aircraft Reactor Experiment Facility, now referred to as Molten Salt Reactor Experiment Facility; (9) Homogeneous Reactor Experiment Facility, now referred to as the Nuclear Safety Pilot Plant; (10) Global Change Research Facility; and (11) various ORNL W'aste Area Groupings.

\section{ENVIRONMENTAL SETTING}

Anderson and Roane counties (Fig. 2) are located in the Great Valley of East Tennessee, a part of the Ridge and Valley Physiographic Province that extends from New York State to Central Alabama (Fenneman 1938). The Great Valley is characterized by numerous elongate, parallel ridges and intervening valleys created by severe faulting and folding. The trend of these valleys is northeast to southwest. Relief in the Ridge and Valley varies as much as 300 feet (Hubbard et al., 1956:5). The terrain is rugged and ranges from moderately steep to very steep.

The underlying rocks are almost wholly sedimentary (mainly limestones and dolomites) of Ordovician age. Also present are some harder shales, sandstones and siltstones. Cherty gravel deposited from eroded limestone and dolomite is present along many of the ridgetops.

The climate classification of the area is the mesothermal (Cfa) hot summer (Koeppe and Delong 1958: 247-254). Regionally, the general air movement in the summer is from the southwest, which results in strong convection currents and locally intense thunderstorms. Although heavy thunderstorms are frequent, the maximum rainfall occurs in the winter and spring months. Precipitation records for the area indicate that about 45 inches occurs annually with a mean annual temperature of $57^{\circ} \mathrm{F}$. Temperatures below $0^{\circ} \mathrm{F}$ and above $100^{\circ} \mathrm{F}$ are rare and periods of prolonged very hot or very cold are unusual.

\section{ARCHAEOLOGICAL BACKGROUND}

A minimum of ten major reconnaissance-level surveys have been conducted on the ORR, with many sufficiently documented in a management plan prepared by the Department of Energy (1983).

The first reported reconnaissance of the area was conducted along portions of the Clinch River by Cyrus Thomas (1894) and reported in the Bureau of American Ethnology. He reported a visit to the Lee Farm Site (40RE27) and a visit to Jones Island (40RE28). 


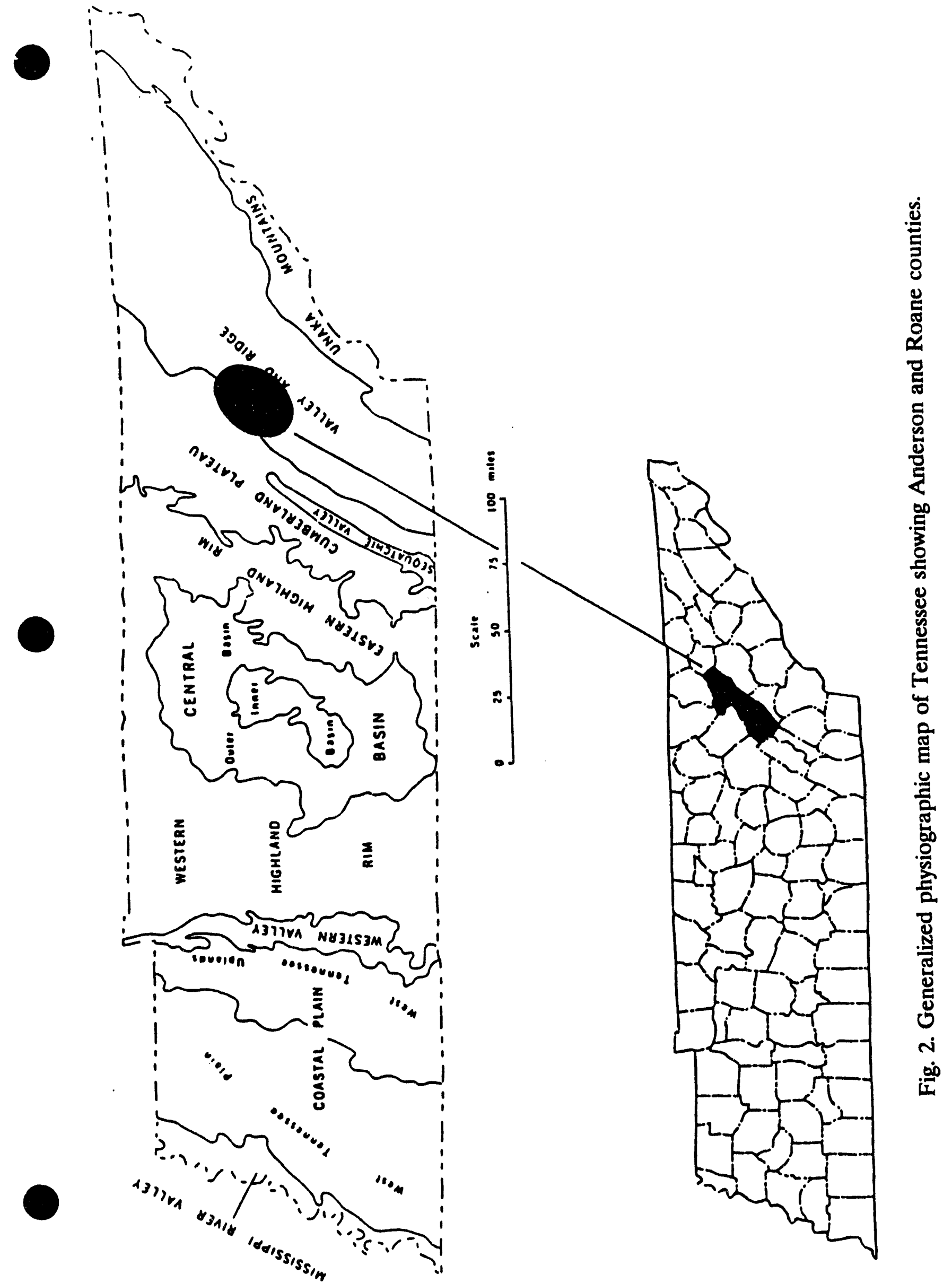


Two Woodland mound sites, the Crawford Farm Mounds (40AN21) and the Freels Farm Mounds (40AN22), located on the ORR were excavated by Webb (1938) during the construction of the Norris Dam.

Construction of the Watts Bar Reservoir resulted in a survey of portions of the Clinch River, mainly in the narrow bench areas and terraces along the main channel. Numerous sites along the course were identified, facilitated by almost ideal survey conditions (Nash 1941).

Construction of the Melton Hill Dam resulted in several investigations by the University of Tennessee (McNutt and Graham 1960; McNutt and Fisher 1961): sites 40AN2 (UT Farm Site), 40AN8 (Freels Bend Site), and 40AN20 (Bull Bluff Site). The most extensively occupied of these appeared to be 40AN20, which contained Woodland, Mississippian and Euro-American artifacts.

During 1972, archaeological investigations were initiated on the proposed site of the Clinch River Breeder Reactor Project (CRBRP). Schroedl (1972) relocated sites 40RE10440RE108 originally recorded during Nash's 1941 survey. Additionally, four historic EuroAmerican farmsteads and a cemetery were recorded.

A follow-up study of the CRBRP site located on the ORR was conducted by Schroedl (1974) following the acquisition of 1940 survey maps from the Tennessee Valley Authority. The major emphasis of the survey was the relocation of the structural areas and a comparison of current conditions to those present at the time of the acquisition of the ORR by the United States Corps of Engineers in 1942. The findings indicated that some of the original locations were intact with all structures present, while others contained no evidence of former structure locations.

Surveys by Fielder (1974) and Fielder et al. (1977) of specific areas of the ORR focused on the prehistoric and historic sites, respectively. The 1974 survey relocated and identified 45 sites dating from the Paleoindian (?) through the Hïstoric Euroamerican Period with no conclusive evidence for any historic Native American occupations within the ORR. The 1977 survey focused on the numerous structures and former structure areas partially noted in previous surveys. A total of 415 structures ranging from houses to barns and sheds was identified. Of these, one structure (The Freels Cabin) was considered eligible for inclusion in the National Register of Historic Places (Fielder 1974:41).

A survey of approximately 1400 acres for the proposed Tennessee Synfuels Associates site was conducted by GAI, Inc., during the summer of 1981 . The survey and testing program relocated and evaluated five previously recorded sites. The overall results included the identification of three cemeteries and associated residential areas and one house complex. Prehistoric site 40RE86 produced undisturbed cultural features and was recommended for inclusion in the National Register of Historic Places (GAI 1981:7).

Jolley (1982) conducted a second survey of the CRBRP site of those areas not evaluated in Schroedl's 1972 survey. The utilization of a thorough shoreline survey, deep-testing program along the floodplain and terraces and a shovel test strategy resulted in the identification of 17 additional sites. 
An archaeological assessment of two historic house sites for National Register eligibility evaluation was conducted on the Jenkins House site (40RE188) and the Jones House site (40RE189) (Faulkner 1988). The assessment utilized subsurface testing to determine if artifact concentrations were present on the sites. The Jones House site and support structures were recommended for inclusion in the National Register of Historic Places due to the relatively intact nature of the site and its early occupation date (ca. 1820). On the other hand, the Jenkins house has been severely effected by modern intrusions and is not considered eligible for inclusion in the National Register of Historic Places.

A survey of the Solid Waste Storage Area (SWSA) 7 encompassed approximately 220 acres of extremely steep and deflated uplands and the low floodplain of Melton Branch (DuVall 1992a). Shovel tests revealed a low density of cultural material over a $15 \times 15$ meter area on a low terrace near Melton Branch. Shovel tests also revealed a very deflated and eroded landform. Based on the shovel tests, site 40RE194 was determined to be an ephemeral encampment of unknown cultural affiliation. No further archaeological investigations were recommended for this site.

An approximately 40-acre reconnaissance of the Remote Handled Transuranic Waste Storage Area (RH-TRU) site contained the Jenkins House site (40RE188) within the boundaries of the project (DuVall 1992b). However, the house site area was scheduled to be excluded from the project area.

Several surveys associated with borrow areas and proposed construction projects on the ORR were conducted in 1991 and 1992. They include the approximately 425-acre Health Physics Research Reactor-Dosimetry Applications Research Facility and Tower Shielding Borrow area (DuVall 1991), the approximately 78-acre Advanced Neutron Source (ANS) Project (DuVall 1991a), the approximately 6500-linear-foot Liquid Low-Level Waste Collection and Transfer System (LLLW-CAT) (DuVall 1991b), the 1-acre Melton Valley Recontour site (DuVall 1991c), a reconnaissance of the M. K. Ferguson Lay-Down Area/West End Treatment Facility (DuVall 1992d), the Pond Waste Management Project on the K-25 Complex (DuVall 1992b), a survey of the Waste Area Grouping (WAG) 11 (White Wing Scrap Yard site) (DuVall 1992c), a reconnaissance of the RH-TRU Waste Storage Bunker (WSB) and Melton Valley Storage TankIncrease Project (MVST-CIP) (DuVall 1992d), an approximately 150-acre reconnaissance of the WAG 2 (White Oak Lake and White Oak Creek floodplain) (DuVall 1992e), a reconnaissance of the approximately 6-acre Low-Level Waste Solidification Retrievable Cask Interim Storage Facility II (DuVall 1992f), a reconnaissance of the Radio Repeater Facility (DuVall 1992g), the East End Monitoring Station (DuVall 1992h), the Y-12 Plant Chestnut Ridge Access Road (DuVall 1992i), and the Y-12 Plant Drilling Staging Area (DuVall 1992j). No archaeological sites were identified on any of the project areas due to large areas of prior disturbance or steep, deflated slopes, in most cases.

A number of negative findings reconnaissance-level surveys were conducted in 1993 and include the approximately 1-acre Radiochemical Engineering Development Center (REDC) (DuVall 1993), the 4000-linear-foot Hydrofracture Facility Pipeline Upgrade (DuVall 1993a), the 
1-acre Office Buildings, 1500 Area site (DuVall 1993b), the 1-acre Waste Management Health and Hygiene Support Facility (DuVall 1993c), approximately 1.2 miles of Tennessee Valley Authority Power Line Relocation (DuVall 1993d), and the 3-acre Environmental Safety and Health Compliance and Training Building (ESHCTB) (DuVall 1993e).

A reconnaissance of the approximately 100-acre Center for Biological Sciences (CBS) site encompassed an Historic Period house site on the northwest corner of the project area (DuVall 1993f). The site had been originally identified during the 1977 Fielder et al. survey of historic sites within the boundaries of the ORR. This site (Inv. No. 5A) was not considered significant at the time due to the physical remains and the probable 20th century origin. The latest reconnaissance identified bulldozed brick chimney remains, a partial stone-lined cellar, stone-lined spring, concrete root or storm cellar, and several piers related to the barn. Artifacts observed included numerous "Mason-" type canning jars, glass and screw-cap bottles. Based on the physical remains, amount of disiurbance and 20th century artifacts, no additional archaeological investigations were recommended for the site.

An archaeological reconnaissance of approximately 24 miles of floodplain and low terraces along the East Fork Poplar Creek as part of an environmental restoration project identified two prehistoric and six historic period sites (DuVall 1992k).

Areas previously surveyed at ORNL are depicted in Fig. 3.

A general chronology of prehistoric habitation of the Tennessee area is presented below. Based upon excavated sites and surface finds, man has occupied the Tennessee area for at least 12,000 years. The generalized cultural sequence found throughout Tennessee will be discussed in the following paragraphs.

The earliest definable occupation of the area occurred during the Paleoindian Period possibly as early as 20,000 years ago. Early man most likely peopled the New World from northeastern Asia via a route across the Bering Straits region between Alaska and Siberia perhaps as early as 30,000 B.C. The extensive glaciers of the late Wisconsin period prubably facilitated this movement of man from the Old World. As the glaciers grew, sea levels fell from 100 to 150 meters and a landbridge, about 1000 to 1500 miles wide, emerged between the continents. Most evidence points to this landbridge as a primary entryway into North America after the late Wisconsin glacial maximum about 18,000 years ago. However, the earliest period of definitive aboriginal cultural development (Paleoindian) in the Tennessee River Valley dates from about 10,000 to 8,000 B.C. This period would have been cooler than today's climate, the southern forest would have exhibited a stronger boreal cast, and the animal life would have included numerous forms that became extinct by the close of the Pleistocene.

The character of the Paleoindian culture in the area suggests that these early nomadic hunters moved about in small family bands numbering perhaps ten to fifteen persons. The activities of these hunters are best known from sites on the High Plains and in the southwestern United States where their tools are found with such now extinct Ice Age Mammals as mastodon, 


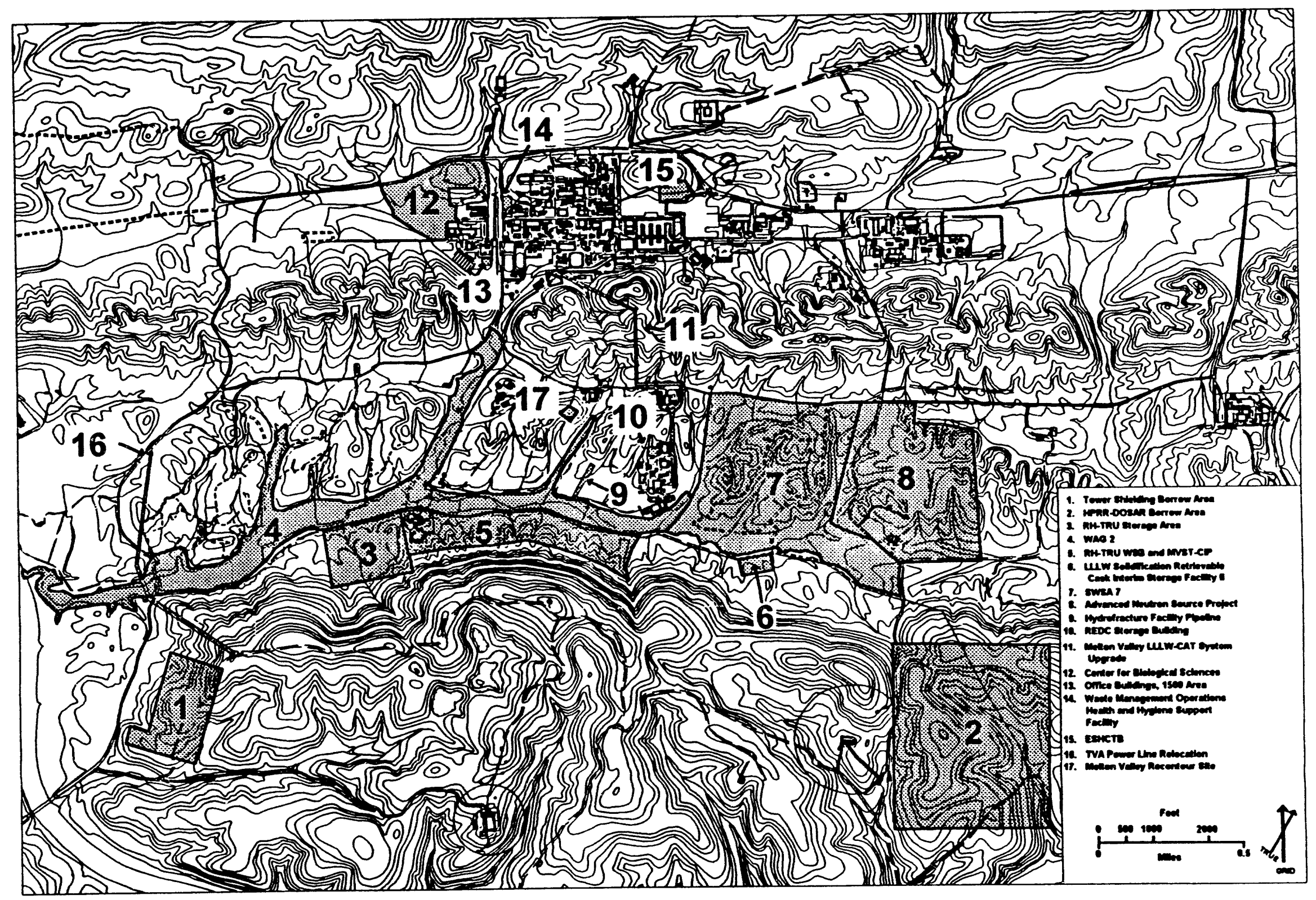

Fig. 3. Boundaries of previously surveyed areas at the Oak Ridge National Laboratory. 
mammoth, ground sloth, tapir, musk-ox, giant beaver, and ancient bison. Most characteristic of the tools of this period are the fluted projectile points, including the Clovis types that are known from numerous sites throughout the United States. Subsistence data beyond the associations with large land mammals are sparse, but several southwestern sites contain tool assemblages that suggest the exploitation of plants as well.

The relationship between the Paleoindian and Archaic Periods in the eastern United States is not well understood, but a continuity of some tool types indicates a continuous technological development from Paleoindian to Early Archaic times even as hunting patterns and social structures were probably undergoing change. The Archaic Period, dating from about 8000 to 1000 B.C. in the Tennessee Valley, has been divided into three divisions by archaeologists: Early (8000-5000 B.C.), Middle (5000-3000 B.C.), and Late (3000-1000 B.C.). These divisions are based primarily upon differences in technology and projectile point forms, with accompanying inferences or speculation about subsistence orientations/strategy and social complexity. The projectile point forms change from corner-notched (Kirk, Cypress Creek), side-notched (Big Sandy), and basal notched (LeCroy, Eva I) forms to stemmed forms (Morrow Mountain, White Springs/Sykes, Benton, Late Archaic Stemmed, Little Bear Creek and Wade) forms.

The Archaic Period generally reflects aboriginal adaptations to a postglacial, warming climate and emerging deciduous forest communities with associated modern fauna. The archaeological record clearly indicates a dependence upon the exploitation of gathered forest resources such as roots, nutfruits, and berries. The extensive exploitation of riverine resources such as shellfish is also recorded in the presence of shellmiddens along inland rivers and streams. Subsistence practices clearly changed from a dependence upon the larger Pleistocene game mammals (now extinct) to smaller mammals. Studies of faunal remains from Archaic Period sites indicate the importance of the bear, white-tailed deer and elk among the larger postglacial mammals and the utilization of numerous other species of smaller mammals, birds, fishes, and mussels as food resources.

Archaic period sites are abundant and are located in all physiographic sections and orographic locations and probably comprise the greatest number of overall components within the Tennessee River Valley. Based upon data from numerous sites in the valley, archaeologist have inferred that small bands of gatherer-hunters inhabited these sites for short periods of time, or seasons, and that these inhabitants may have followed some sort of seasonal migratory pattern which would bring them closer to available floral and faunal resources as these ripened or became accessible for harvest. The effects of these changing adaptations and hunting strategies are reflected in patterns of increasing population density and degrees of social complexity as well as a more sedentary existence over time. The basic social unit probably increased in size from the small family bands of 10 to 15 individuals to macrobands of as many as 50 to 100 individuals during some portions of the seasonal-round. At any rate, the reported sites are both larger and often contain higher artifact densities than those recorded for the Paleoindian components. Additionally, many locations appear to be reoccupied over hundreds and even thousands of years. By the close of the period the rudiments of simple agriculture appear and harken changes to follow. 
Other cultural innovations from this period include fish weirs, houses, or shelters with compacted clay floors, stone bowls, human cremations, and perhaps the first cloth of plaited vegetable fibers, and very late in the period, the introduction of ceramic vessels tempered with plant fibers. Stone-working technology expanded and the new tool types are present in site assemblages. The spearthrower, or ahtlatl, came into use along with adzes and ground-stone implements such as axes, celts, etc. There is a marked increase in tools for working wood and a decrease in the earlier specialized bone-working tools.

Following the Archaic Period, and beginning about 1000 B.C., cultural innovations and additions begin to occur, particularly in the central Ohio Valley and along the Gulf Coast. These changes are also reflected in the changing cultural adaptations in the Tennessee and Cumberland River Valleys and their tributaries. The innovations were signaled most notably in the archaeological record by the appearance of pottery, elaborate mortuary earthen mound construction, increasing widespread plant domestications and/or cultivation, and increasing sedentism with some corresponding population increases. The Woodland Period, dating from about 1000 B.C. to A.D. 900 in the Tennessee area and southeast, in general, has been divided into three parts: Early (ca. 1000 B.C. to 200 B.C.), Middle (ca. 200 B.C. to A.D. 600 ), and Late (ca. A.D. 600 to A.D. 900). These divisions are based primarily upon technological changes and the presence/absence of certain elaborate mortuary characteristics. These differences in mortuary treatments indicate the emergence of a non-egalitarian social order. Systems of exchange (trade) can also be inferred from the distributions of raw material and finished objects across long distances in the eastern United States. The domestication of plants which began in the Late Archaic also continues and expands in the kinds of plants being cultivated. Maize (corn) may have been introduced by Middle Woodland times, and it was most certainly present by Late Woodland times.

Additional technological innovations include ceramics and the first inferred use of the bow-and-arrow. Ceramic types include Long Branch, Baumer, Mulberry Creek, and numerous other types. The lithic technology also reflects changes with a marked decrease in the overall size of projectile points and changes in form. Projectile point types include Cotaco Creek, Adena, Motley, Copena, Bakers Creek, Middle Woodland Stemmed, Jacks Reef Pentagonal, Knight Island and Hamilton, to name a few. The forms change from the stemmed types of the Late Archaic/Early Woodland to the triangular stemless forms. The first clear indications of structural forms and village patterning are available from excavations of Woodland villages in the Tennessee River Valley, but little data are available on the erection of elaborate earthen features and mortuary complexes since these remain to be reported in the literature or have been destroyed before scientific investigations could be undertaken.

The Mississippian Period (A.D. 900 to Protohistoric) represents the climax period in indigenous cultural development in the East. This cultural adaptation developed in the Mississippi Valley and diffused, both directly by migration of peoples in some areas and indirectly through the spread of ideas, sparking in situ development in other areas across a large portion of the Southeast. The adaptation is marked by a dependence upon horticulture (hoe agriculture) for its basic, storable food supply. The gradual shift during the Woodland Period to a substantial dependence upon cultigens for a dependable food source tied societies to specific locations, 
emphasized territoriality and control of land, provided a steady supply of food that permitted population growth and expansion, encouraged specialization of labor, provided for the growth of long distance exchange networks, and led to the development and spread of religious ceremonies associated with particular crops (e.g., busk or green-corn ceremony of first fruits). Sociocultural complexity increased with the emergence of a chiefdom-level of sociopolitical complexity and its concomitant ranking system.

The agricultural complex included several varieties of maize, squash, pumpkin, gourd, sunflower and beans. The addition of these cultigens to the wide variety of gathered native fruits, berries, and roots provided, along with hunting, an ample supply of food and support for redistributive cultural mechanisms often associated with chiefdoms and communal or public ceremonial constructions. This more efficient economy brought an increase in population in the central Mississippi Valley area, and it also served as a major force in the expansion of this cultural adaptation into other areas with favorable growing seasons and soils.

The various sites also reflect a system that was not egalitarian since there are obvious size and functional differences in the sites. The larger center that contained pyramidal (temple or platform) mounds were often fortified with stockades enclosing large areas about the mounds. These sites were the main population centers and the residences of the social, political, and ideological elites of the society.

These centers are often associated with a number of larger settlements or villages in the vicinity. Smaller settlement units could include hamlets, or a small cluster of houses, and farmsteads, or individual houses. The smaller villages and outlying farming communities would contain the bulk of the population and presumably serve as production units for consumption in the larger, predominantly ceremonial mound centers. The latter would contain the central control function of the system and contain a range of domestic and civic structures as temples, charnel structures, and/or elite residences. Each of these sites would contain cemetery precincts, and one of the hallmarks of this culture along the Cumberland River system in Tennessee is the use of stone coffins or stone-boxes in which the dead were placed.

The archaeological record for the Protohistoric Period (ca. A.D. 1450 to A.D. 1750) is sparse. The major population centers in portions of the Tennessee Valley and northward into the Cumberland River Valley of Tennessee and Kentucky during this time period had been abandoned. North of the Tennessee Valley, the Nashville Basin area was variously reported as an area reserved for hunting by the Shawnee, Chickasaw, and Cherokee tribes, and the Shawnee were reportedly expelled on two occasions (1715 and 1745) by the latter two tribes (Swanton 1946:117).

\section{HISTORIC}

Although early historic Indian (Cherokee) sites probably exist in the area, none are recorded for the project area. A number of sites of this description may occur in the area from conflicts between early white settlers and the Indians. 
With the land sale by the Cherokees to the United States government in 1791, a series of military posts were eventually established to protect the whites from hostile Indian attacks. One of these was located at the mouth of the Clinch River (named Southwest Point) replacing John Sevier's territorial militia post.

The area economy was based upon agriculture throughout its early (and later) history, although some of the early industries included milling, iron works, blacksmithing, gunsmithing, and tanning. By the mid-nineteenth century farming dominated as scientific methods increased productivity even in the poor soils of the area. However, after the Civil War, the large farms began to decrease in size with the sale of parcels and an increase in the timber industry.

During the late 1930s major undertakings by the government included archaeological projects conducted under the Work Projects Act (W.P.A.) program, Watts Bar Reservoir and in 1942 the United States Army Corps of Engineers purchased 37,000 acres in 866 tracts of land for the Manhattan Project.

\section{METHODOLOGY}

The Phase I reconnaissance and evaluation of the project consisted of a pedestrian and vehicular survey of the specific facility boundaries. The boundaries and interior portions of the developed areas were systematically observed to facilitate an accurate picture of existing conditions at ORNL.

Aerial photography, both black and white and infra-red, were used to determine existing vegetation patterns and plantings indicative of prior disturbance.

Notes were taken on all sections and depicted terrain features, disturbances, vegetation patterns, and the probability for archaeological sites. Cultural material identified was collected, bagged for transportation to the laboratory, and labeled with the provenance. All personnel, material and equipment used to recover artifacts are scanned for radiation contamination prior to removal from the ORR.

Due to the nature of the reconnaissance, no shovel tests were excavated on the basis of severe disturbance or excessive slope observed throughout the ORNL main facilities complex. However, limited shovel testing was conducted in some areas where the potential for contaminated soils were minimal. Areas where the degree of disturbance could not be accurately determined were also investigated by the placement of $40 \times 40$ test units.

All field notes, photographs and maps are on file at DuVall \& Associates, Inc., 407 Church Street, Franklin, Tennessee 37064. 


\section{COORDINATION WITH STATE AGENCIES}

A search of the site files and coordination with the Tennessee Division of Archaeology indicated that sites 40RE132, 40RE188, 40RE189, and 40RE194 were located in the surveyed areas.

A search of the National Register of Historic Places and a review of the site files at the Tennessee Historical Commission indicated that two properties included in the National Register of Historic Places currently lie within the surveyed area. The Graphite Reactor and New Bethel Baptist Church and Cemetery are currently included in the National Register of Historic Places. The Graphite Reactor (Building 3001) lies within the ORNL main facilities complex and is currently open to the public as an exhibit.

The New Bethel Baptist Church and Cemetery lies northeast of the ORNL main facilities complex and north of Bethel Valley Road. The plan and boundaries of the church and cemetery taken from the National Register of Historic Places nomination form can be seen in Fig. 4 .

\section{RECONNAISSANCE RESULTS}

The reconnaissance investigated nine major areas and several ORNL support facilities. The following paragraphs present a brief description of the area including observations and general impressions of the current conditions.

\section{ORNL MAIN FACILITIES COMPLEX}

The ORNL main facilities complex was the largest area reconnoitered during the investigation with approximately 560 acres (Fig. 5). A general boundary of the survey area is the foot slopes along the north face of Haw Ridge on the south, WAG 3 on the west, the south slope of Chestnut Ridge on the north and the easternmost road in the East Support Area to the east. Several support facilities located north of Bethel Valley Road and the ORNL main facilities complex that were surveyed as part of the main facilities complex include (1) ORNL Security Patrol Firing Range; (2) 161-kV Substation, Building 0901; (3) Main Reservoir, Building 0902; (4) ORNL Visitor Overlook and Parking Area; and (5) Compactible Waste Facility (see Fig. 5).

The initial impression when driving through the ORNL main facilities complex, which is located in Bethel Valley, is that of severe disturbance. Evidence from both photographs and maps suggests that this is not a recent event but has occurred over five decades. This impression becomes even more evident when walking the area. The interior, or secured, area within the main facilities complex has been totally destroyed by the construction of buildings, ponds, demolition of structures, and rebuilding on the demolition sites. 


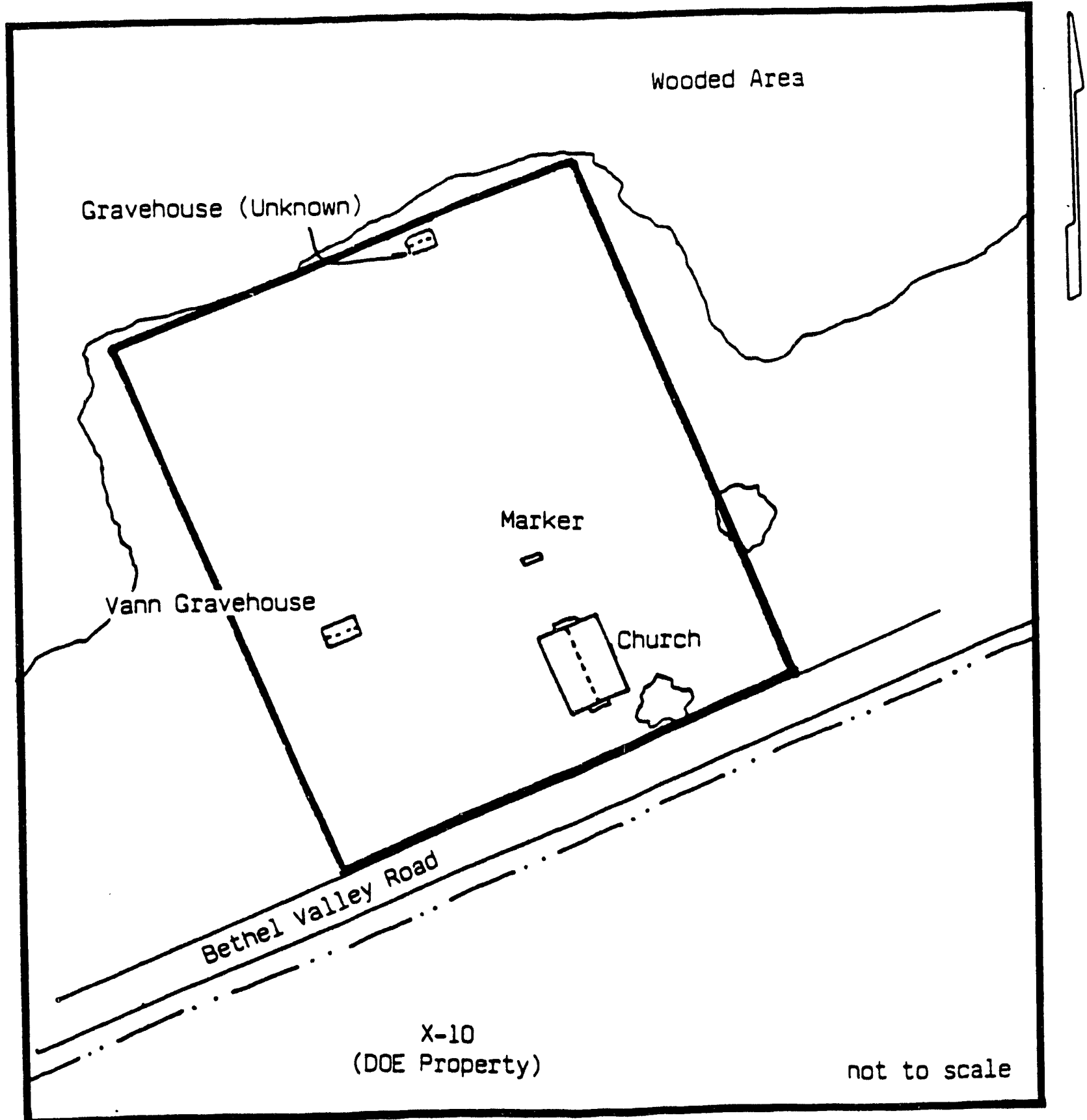

Fig. 4. Boundaries of the New Bethel Baptist Church and Cemetery. 


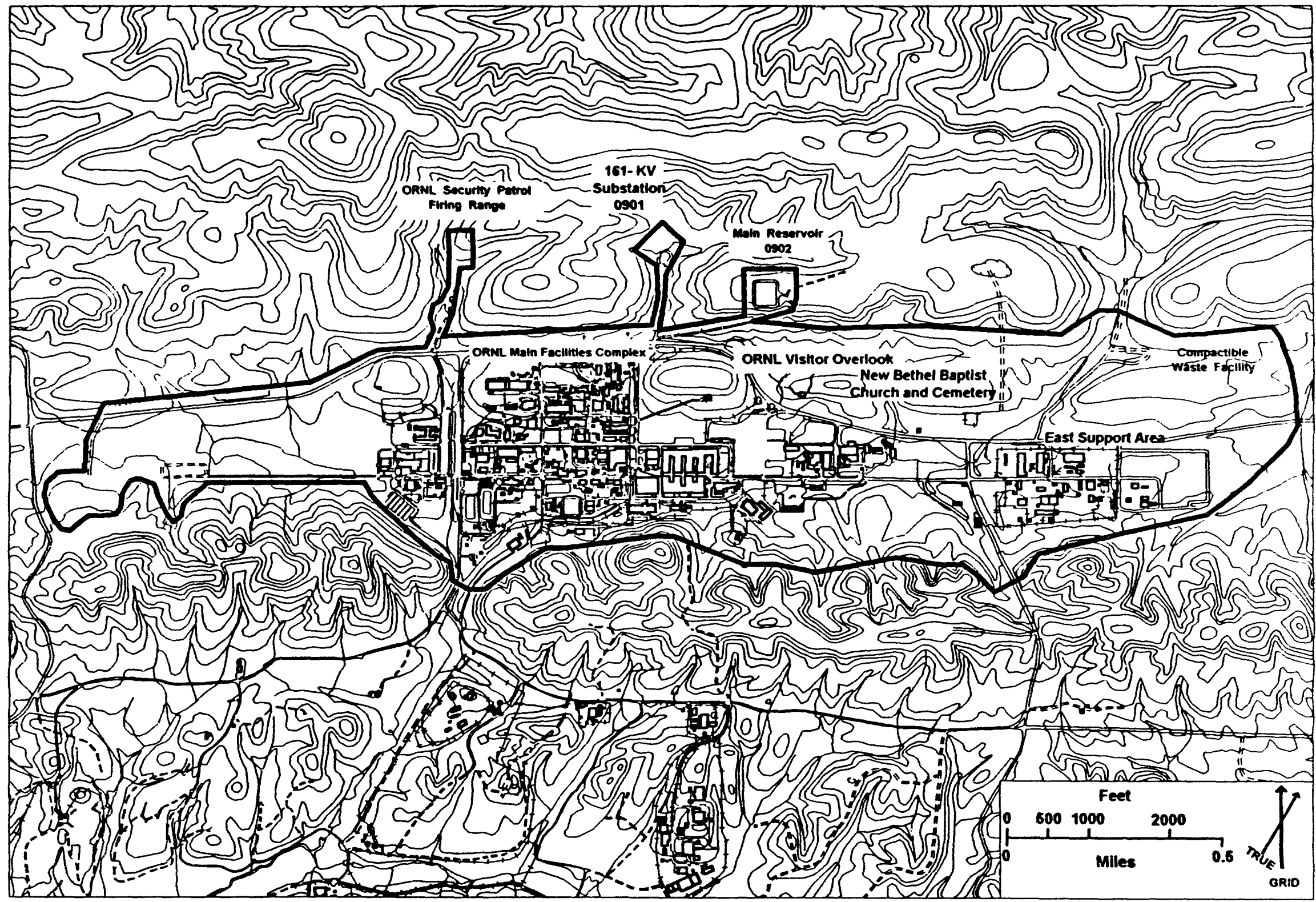

Fig. 5. Boundary of area surveyed as part of the Oak Ridge National Laboratory main facilities complex. 
The area outside the secured area likewise shows evidence of severe disturbance in the form of recontoured landforms, borrow areas, roads that no longer exist, clay/chert soils, and planted pines. This is especially evident along Bethel Valley Road where terrain alteration in old fields is obvious due to drastic changes in the landform from level to graded slopes. Early photographs showing initial construction phases at the ORNL main facilities complex can be seen in Plates 1 and 2.

The area northwest of Bethel Valley Road has also been developed with support facilities for ORNL. An active facility, the Compactible Waste Facility, is located within a hollow on the north edge of the study area. The landfill occupies approximately 25 acres and was initially cleared to red clay. The low ridgeline which lies south of the landfill has been partially borrowed along its crest with clay and chert gravel soil on the undisturbed portions. Limestone, or dolomite, outcrops on the slopes.

The ORNL Visitor Overlook and Parking Area is located approximately 1000 feet west of the New Bethel Baptist Church. The overlook lies on the south slope of Chestnut Ridge, and the parking lot and access road are located adjacent and to the west of the overlook. The entire area around the overlook, parking lot, and access road has been severely disturbed to bedrock, in most cases. Bedrock and clay soils was observed throughout the area.

The Main Reservoir, Building 0902, occupies approximately 12 acres of a hilltop northwest of the ORNL Visitor Overlook. The large, square concrete reservoir measures approximately $200 \times 200$ feet and lies within a security-fenced area. The area outside the fence contains sparse vegetation cover with cherty soils. All indications are that the hilltop has been leveled. A paved access road, which is approximately $18 \mathrm{~W}$ feet in length, follows the slope from Bethel Valley Road to the hilltop.

The 161-kV Substation, Building 0901, is located at the end of an access road approximately 1000 feet north of Bethel Valley Road (Plate 3). The access road has a cleared width of approximately 100 feet exclusive of the road bed. The substation proper occupies an area estimated at two acres with numerous transmission lines radiating from the station. The transmission line right-of-ways have also been cleared and appeared to be, minimally, 100 feet in width.

The Kingston Demolition Range Map (Tennessee Valley Authority 1942) indicated two structures were present along the access road to the $161-\mathrm{kV}$ Substation. One was located on the east side of the road, and the other was located at the roads terminus in the hollow. Neither Fielder's (1977) survey nor this reconnaissance identified any structural remains adjacent to the access road.

The ORNL Security Patrol Firing Range is located in a hollow and is serviced by a gravel access road (Plate 4). Approximately five acres are included in the range and support areas. A large cut has been made in the hill slope to produce a backstop or impact area. The firing line and range has also been leveled with several Butler-type buildings around the perimeter. Just south of 


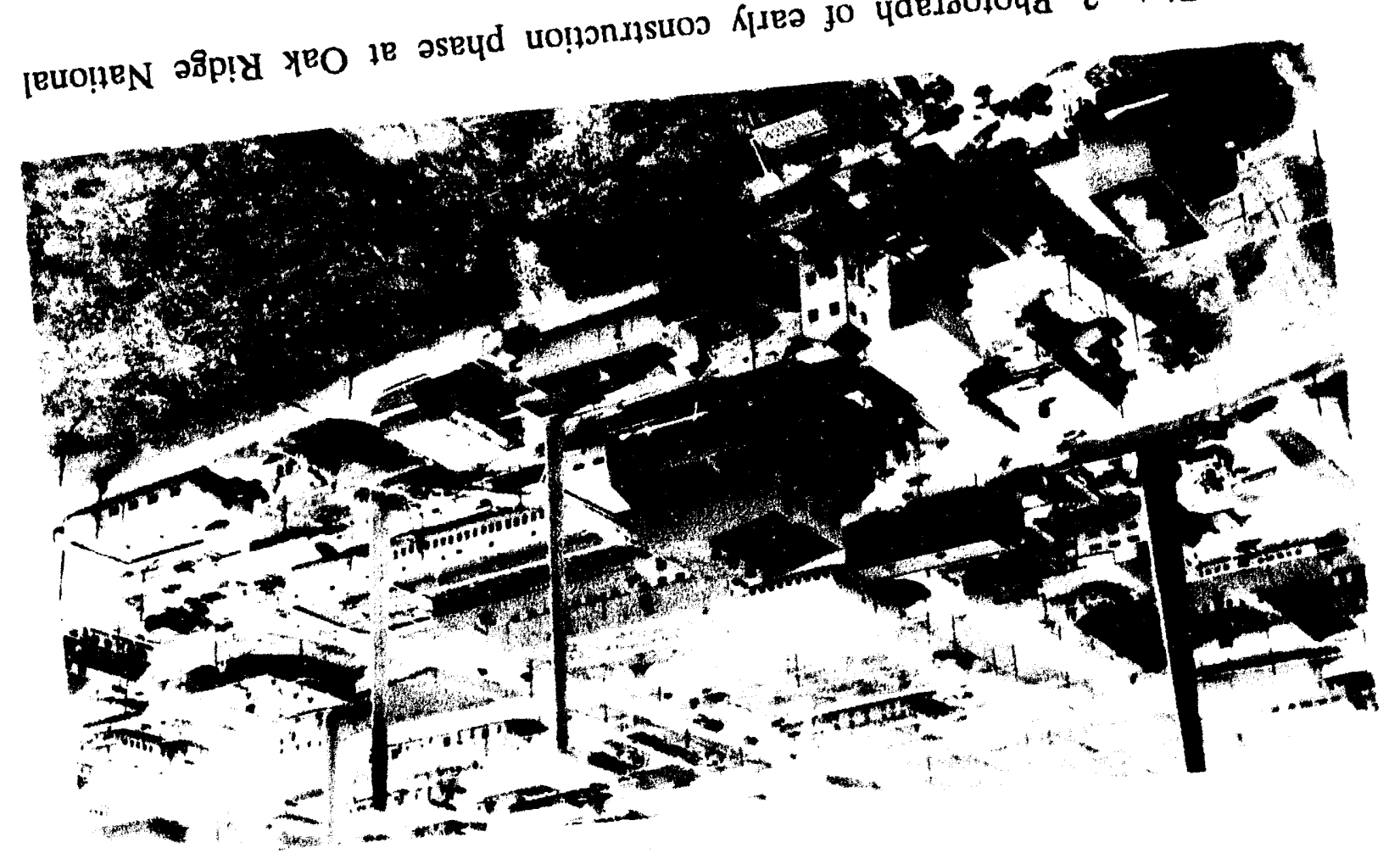

- SrotejoqeT

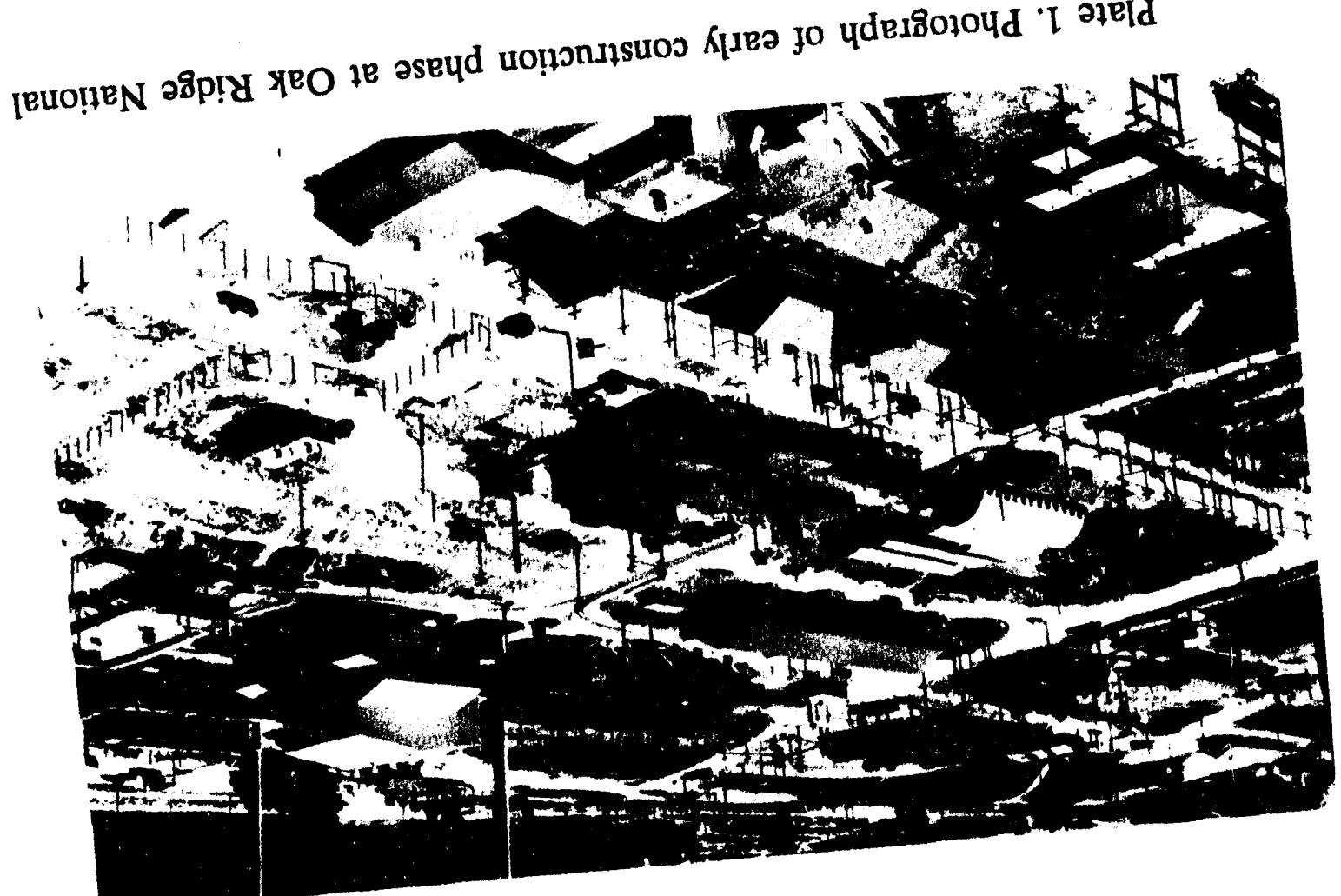




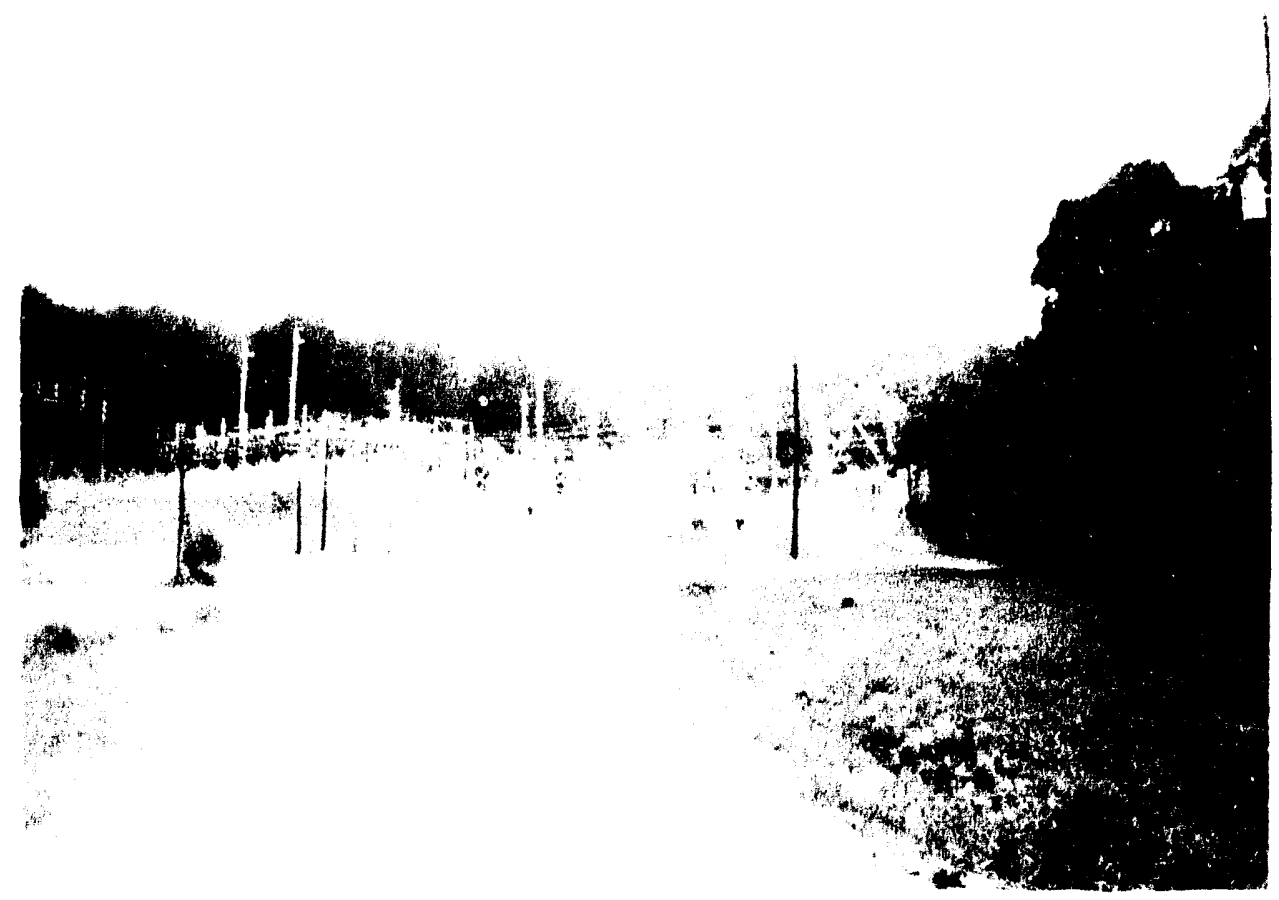

Plate 3. 161-kV Substation Building 0901, located due north of the Oak Ridge National Laboratory main facilities complex.

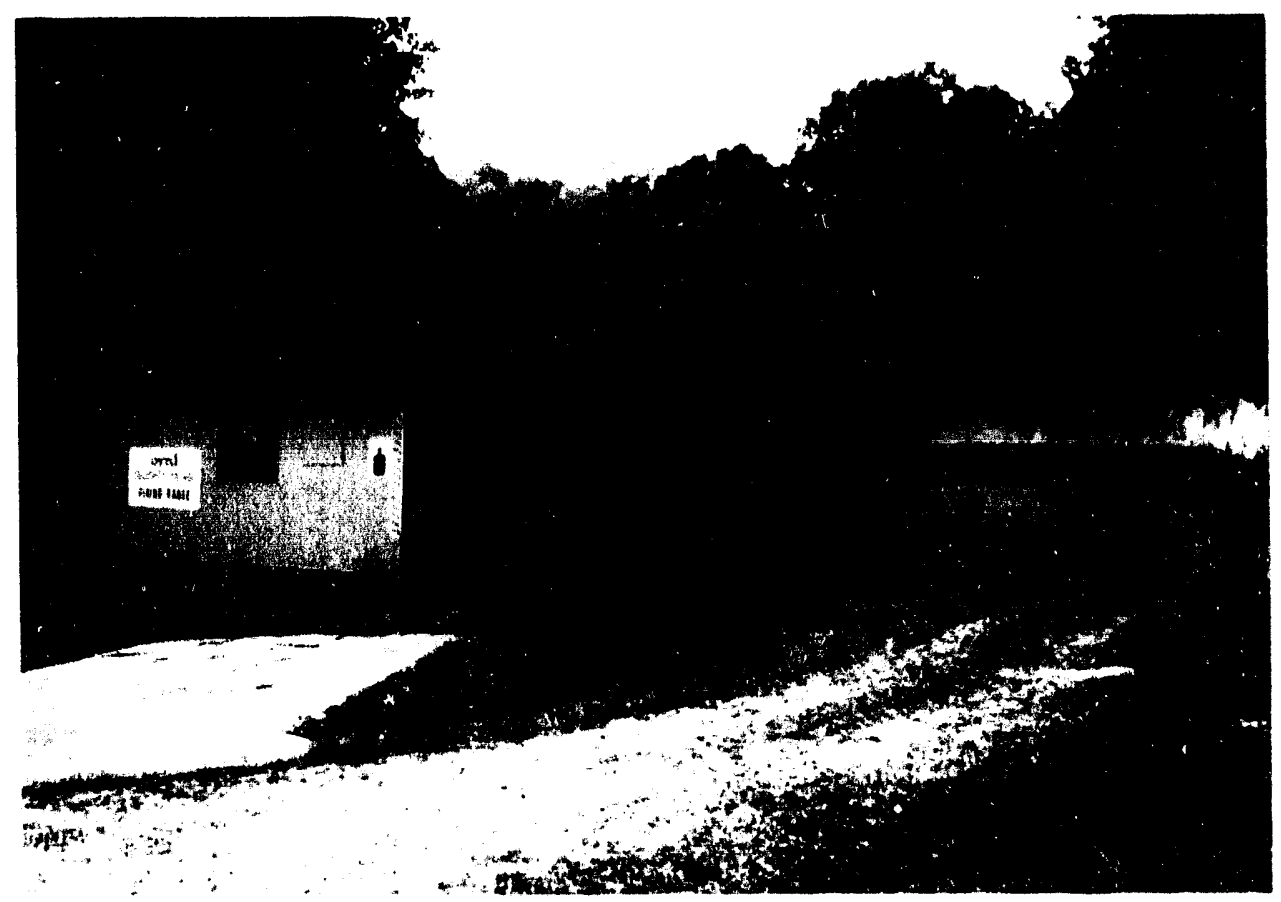

Plate 4. Oak Ridge National Laboratory Security Patrol Firing Range, located northwest of the ORNL main facilities complex. 
the range proper are several steel ammunition bunkers. The entire area, including the access road, has been heavily disturbed.

The extreme west end of the area surveyed as part of the ORNL main facilities complex consists of WAG 3, an environmental restoration unit composed of SWSA 3 and the ORNL Contractor's Landfill. The Contractor's Landfill contains approximately 15 acres of earth-covered construction debris. Due to the amount of earthfill, the original morphology of the landform could not be determined. The open landfill area is surrounded by vegetated slopes on the south side, SWSA 3 on the east, and vegetated flat land on the north and east.

The reconnaissance of the ORNL main facilities complex and support areas failed to identify any archaeological sites. The very heavy disturbance to the surveyed area during the initial construction years and development of ORNL through the 1980s have altered the terrain in virtually all sections of the valley, and to some extent, along the slopes and ridgetops. No additional archaeological investigations are recommended for the previously discussed areas.

\section{TOWER SHIELDING FACILITY}

The Tower Shielding Facility (TSF) encompasses approximately 25 acres of hilltop and slope (Fig. 6). The site consists of four towers and support facilities including a large underground control building (Plate 5). The purpose of the TSF is for the study of radiation shielding for longrange bombers. This secured facility is located approximately 11,000 linear feet south-southeast of the ORNL main facilities complex and is serviced by a single road from the west that intersects State Route 95 approximately 0.75 miles south of White Oak Lake and Dam.

The pedestrian reconnaissance of the facility revealed that heavy borrowing activities had taken place over the tract. It is suspected that most of the soil was used for covering the main control building. Several feet of earth covers the control building for protection from radiation during experiments.

The northern section of the facility is primarily slope which has been severely damaged by earthmoving. Likewise, the main hilltop has been disturbed by both borrowing and filling activities on and about the TSF. The steep east slope contains vegetation cover in the form of mixed hardwoods of no more than 20 years in age. The south slope is steep with a small portion of undisturbed slope extending southward to a graded salvage yard. The east slope is vegetated with mixed hardwoods. The east slope is steep and deflated but does not appear to have been disturbed during the building phases of the TSF.

The slope and hilltop soils were identical and consisted of heavy clay with cherty gravel inclusions. Prior to the construction of the TSF, the area would have been a very low probability area for archaeological sites due to the steep slopes and distance to water. No cultural material was observed within the boundaries of the TSF during the reconnaissance. 


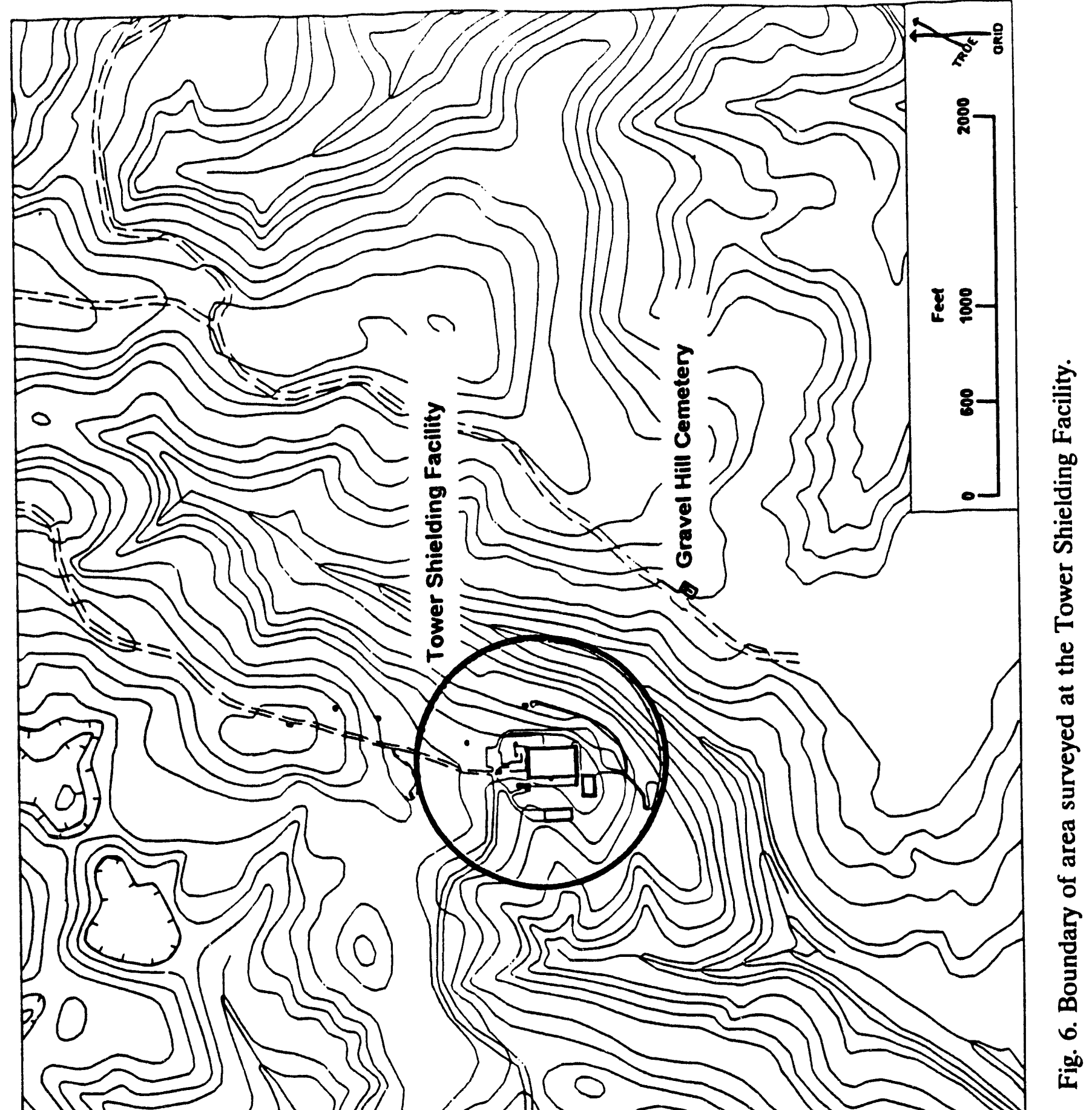




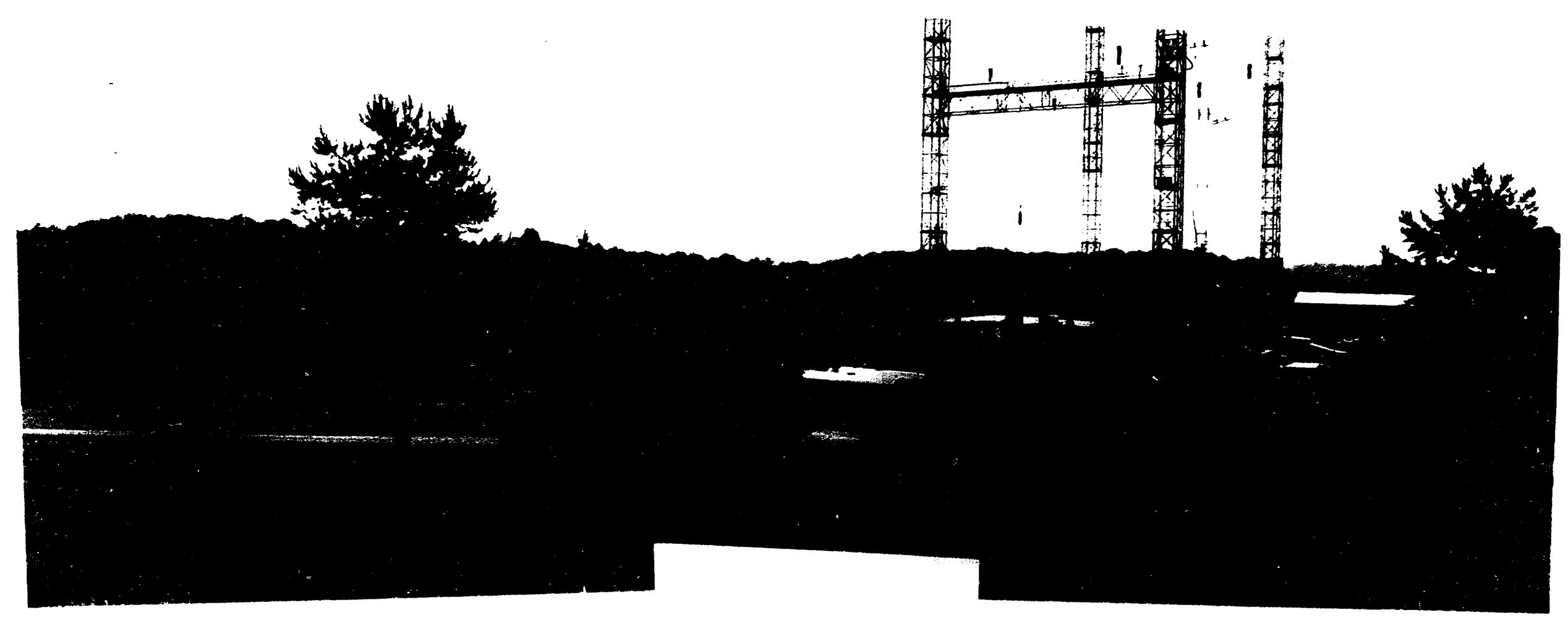

Plate 5. Panoramic view of the Tower Shielding Facility. 


\section{OLD AND NEW HYDROFRACTURE FACILITIES}

The Old and New Hydrofracture Facilities are located on the north and south side of Melton Branch, respectively (Fig. 7). The purpose of the facilities was to dispose of liquid lowlevel wastes (LLLWs) through the drilling of deep wells and the injection of LLLWs mixed with grout into deep shale formations. The Old Hydrofracture Facility, which is located north of Melton Branch, was activated in 1964. The New Hydrofracture Facility was activated in 1980 and is located approximately 100 feet south of the Old Hydrofracture Facility.

The two hydrofracture facilities are confined to approximately two 5-acre tracts within security-fenced areas. As noted in many of the developed areas at ORNL, disturbance from construction activities was extremely heavy. Much of the area within the security-fenced areas is covered with gravel or asphalt pavement. No cultural material was observed at either facility.

\section{HIGH FLUX ISOTOPE REACTOR EXPERIMENT FACILITY AND AIRCRAFT REACTOR EXPERIMENT FACILITY/MOLTEN SALT REACTOR EXPERIMENT FACILITY}

The High Flux Isotope Reactor Experiment Facility (HFIR) occupies an area of approximately 95 acres southeast of the ORNL main facilities complex within a security-fenced area (see Fig. 7). The facility contains approximately 42 buildings or structures and several large parking areas.

The pedestrian reconnaissance of the areas outside the central HFIR again identified large areas of disturbance. The ridgetop and slope adjacent to and west of the HFIR access road was investigated and found to have been partially borrowed on the west slope with numerous roads cut along the ridgetop proper. No evidence of cultural material was noted on the ridgetop.

The Aircraft Reactor Experiment Facility/Molten Salt Reactor Experiment Facility (ARE/MSRE) is located adjacent to and south of Melton Valley Drive and approximately 600 feet north of the central portion of the HFIR (see Fig. 7). The ARE/MSRE contains approximately 2 acres which is covered with buildings, asphalt pavement and recontoured terrain. The amount of disturbance resulting from several episodes of construction at the ARE/MSRE has destroyed the entire original ground surface.

No archaeological materials were identified in the HFIR and ARE/MSRE survey area. Due to the large amount of disturbance at the HFIR and ARE/MSRE, the potential for archaeological sites is low, and no additional archaeological investigations are recommended for the tract. 


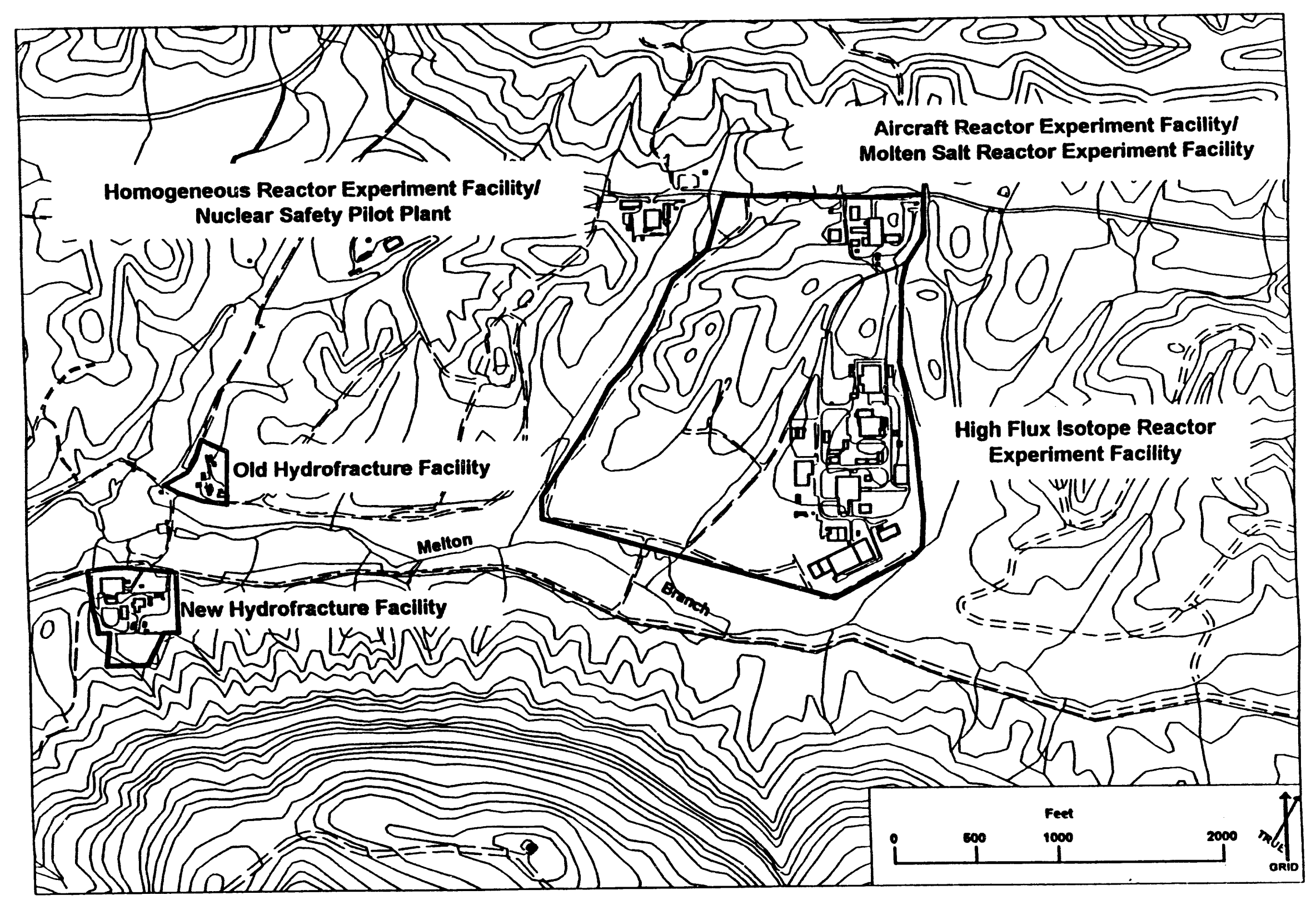

Fig. 7. Boundaries of area surveyed at the Old and New Hydrofracture Facilities, High Flux Isotope Reactor Experiment Facility, and Aircraft Reactor Experiment Facility/Molten Salt Reactor Experiment Facility. 


\section{WASTE AREA GROUPINGS}

The WAGs not associated with the ORNL main facilities complex and/or major ORNL satellite facilities have been combined under this section because they serve/served similar functions, such as waste disposal/treatment, have experienced similar ground-disturbing histories, and typically contain radiation hazards. ORNL WAGs are environmental restoration units that consist of one or more Solid Waste Management Units (SWMUs). A SWMU can be composed of a variety of waste types ranging in size from individual mercury or petroleum product spill sites to units as large as a SWSA, which could consist of a combination of solid waste trenches, individual spill sites, contaminated buildings, and other smaller environmental restoration sites.

ORNL WAG areas that were reconnoitered during this survey are shown in Fig. 8. As previously noted, the WAGs/SWSAs previously surveyed at ORNL include WAG 2, the portion of WAG 8 that consists of Melton Valley LLLW-CAT system line that passes over HAW Ridge between the HFIR site and the ORNL main facilitis complex, and the New Hydrofracture Facility which composes a portion of the WAG 5 (compare Figs. 3 and 8). The area encompassed by WAG 1, which contains SWSA 1 and 2, WAG 3, and WAG 17 were reconnoitered as part of the ORNL main facilities complex and were addressed above. They are encompassed by the Old and Now Hydrofracture Facilities, which compose a portion of WAG 5, and the main body of the WAG 8 (south of Melton Valley Drive), which includes the HFIR and ARE/MSRE sites, were also addressed above. The area encompassed by WAG 9, which is composed of the Homogeneous Reactor Experiment Facility, is addressed below in a following section. WAG 18 encompasses the Experimental Gas-Cooled Reactor Facility/Robotics and Process Systems Complex and is also addressed in a following section. The remaining WAG areas, WAG 4, the main body of WAG 5, WAG 6 , WAG 7, WAG 12 , and WAG 13, are addressed below in this section.

Lursory review of these WAG areas was conducted to determine the current condition within each area. It was found that most of these lie behind security fences and all have been subjected to severe earthmoving activities. The storage areas are located in trenches or retrievable facilities and capped with earth or asphalt (Plate 6). In general, disposal areas (inactive SWSAportions of WAGs) lie on the flatter areas or at the crests of topographic highs/ridges. In some cases, the steep slopes are undisturbed.

The only known site within the WAG areas was located in WAG 6 (SWSA 6). Site 40RE132 was located on the right bank of White Oak Creek and had been heavily damaged by activities within WAG 6 during its active days as SWSA 6 (Plate 7). The site was attributed to Woodland and Archaic occupations based on the recovered artifacts (Fielder 1974:63). The Tennessee site form indicated that follow-up stripping of the site failed to identify any cultural features.

The reconnaissance revealed that all habitable areas within the WAGs have been destroyed. Several areas with steep slopes or in shallow hollows retain some integrity but are areas of low probability for archaeological sites. No additional archaeological investigations are recommended for the existing WAG areas. 


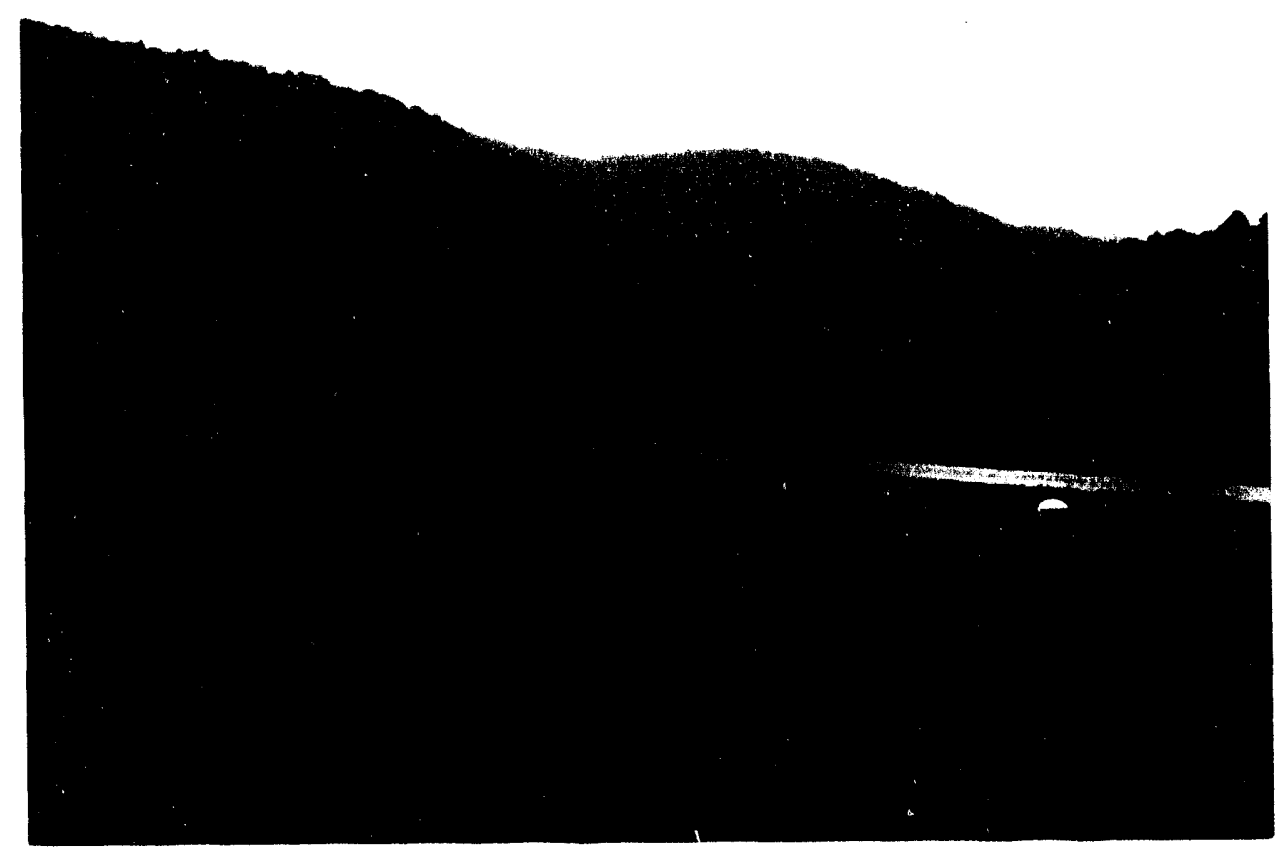

Plate 6. Typical view of a Waste Area Grouping.

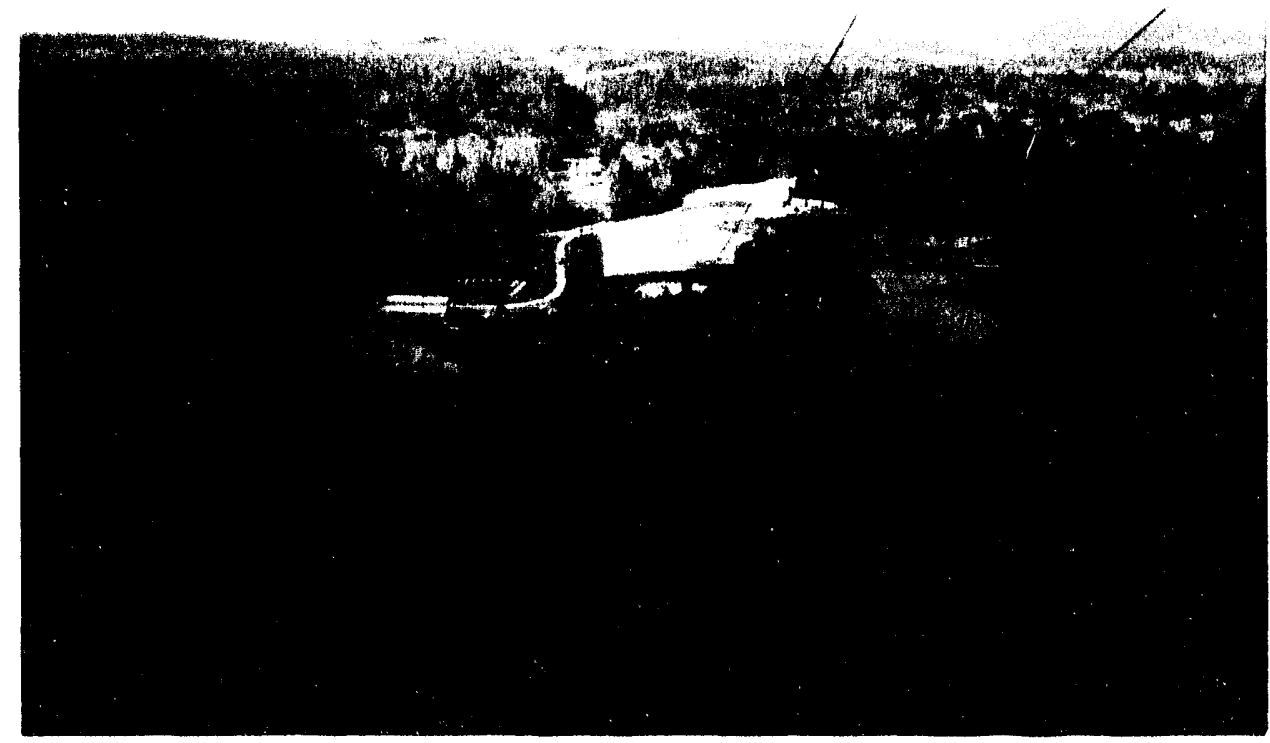

Plate 7. View of Waste Area Grouping 6 with White Oak Lake (WAG 2) in foreground. 


\section{DOSIMETRY APPLICATIONS RESEARCH FACILITY AND HEALTH PHYSICS RESEARCH REACTOR}

The Dosimetry Applications Research Facility (DOSAR) and Health Physics Research Reactor (HPRR) are located approximately 12,000 linear feet east-southeast of the ORNL main facilities complex (Fig. 9). The two facilities are located in narrow hollows and accessed by paved roads (Plate 8). The DOSAR site covers approximately 14 acres of cleared slopes and hollow, while the HPRR site and road encompass approximately 5 acres of like terrain.

The reconnaissance revealed that the hollows and slopes within the sites had been recontoured during the initial construction phase (1962). No additional archaeological investigations are recommended for the two facilities.

A secondary area associated with and north of the DOSAR and HPRR sites consists of a water tank that occupies approximately 1 acre of graded uplands. No undisturbed areas were observed and no cultural material was identified.

\section{EXPERIMENTAL GAS-COOLED REACTOR FACILITY/ROBOTICS AND PROCESS SYSTEMS COMPLEX}

The Experimental Gas-Cooled Reactor Facility/Robotics and Process Systems Complex (EGCR/RPSC) is located on a high hill overlooking the Clinch River/Melton Hill Lake (Fig. 10). The reactor and support facilities encompass approximately 35 acres of recontoured landforms. The reactor proper sits near the edge of an approximately 60 -foot bluff opposite Gallaher Bend. The outer boundaries of the tract generally follow the unvegetated sections of the tract. A small wooded section consisting of pines, hardwoods, and scrub is present on the north end of the tract. This area is currently under successional recovery with red clay soils on the ground surface.

The tract has been totally recontoured. The present EGCR/RPSC site is located on an area containing both cut and filled terrain. A secondary borrow area lies just northwest of the EGCR/RPSC site and extends to the natural wooded slopes.

Based on the observed disturbance, no additional archaeological investigations are recommended for the tract. 


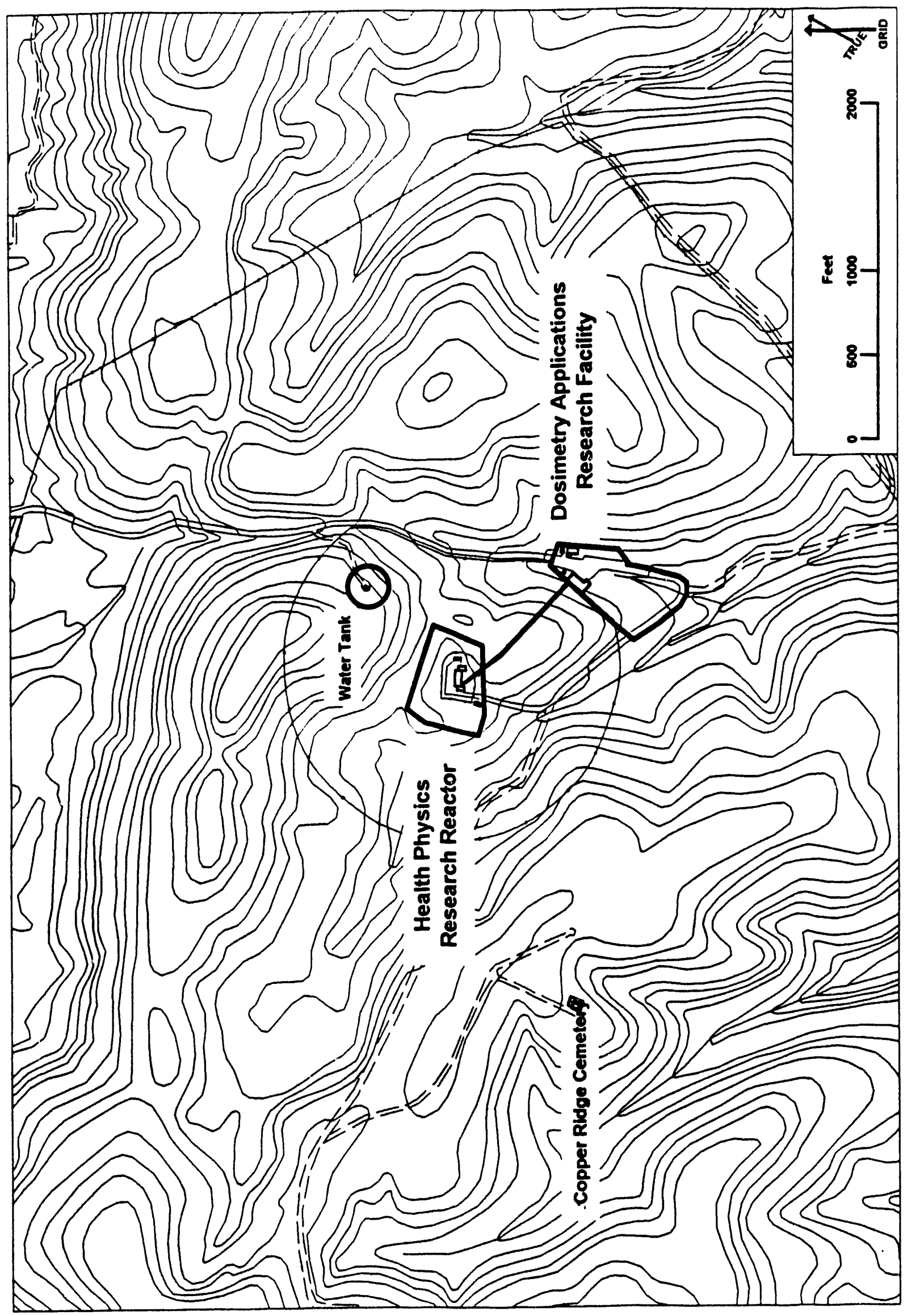

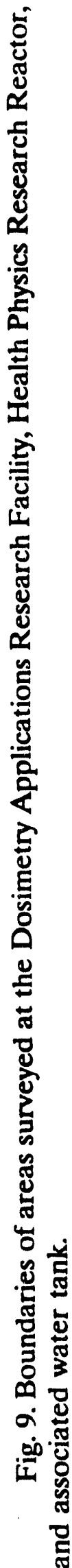




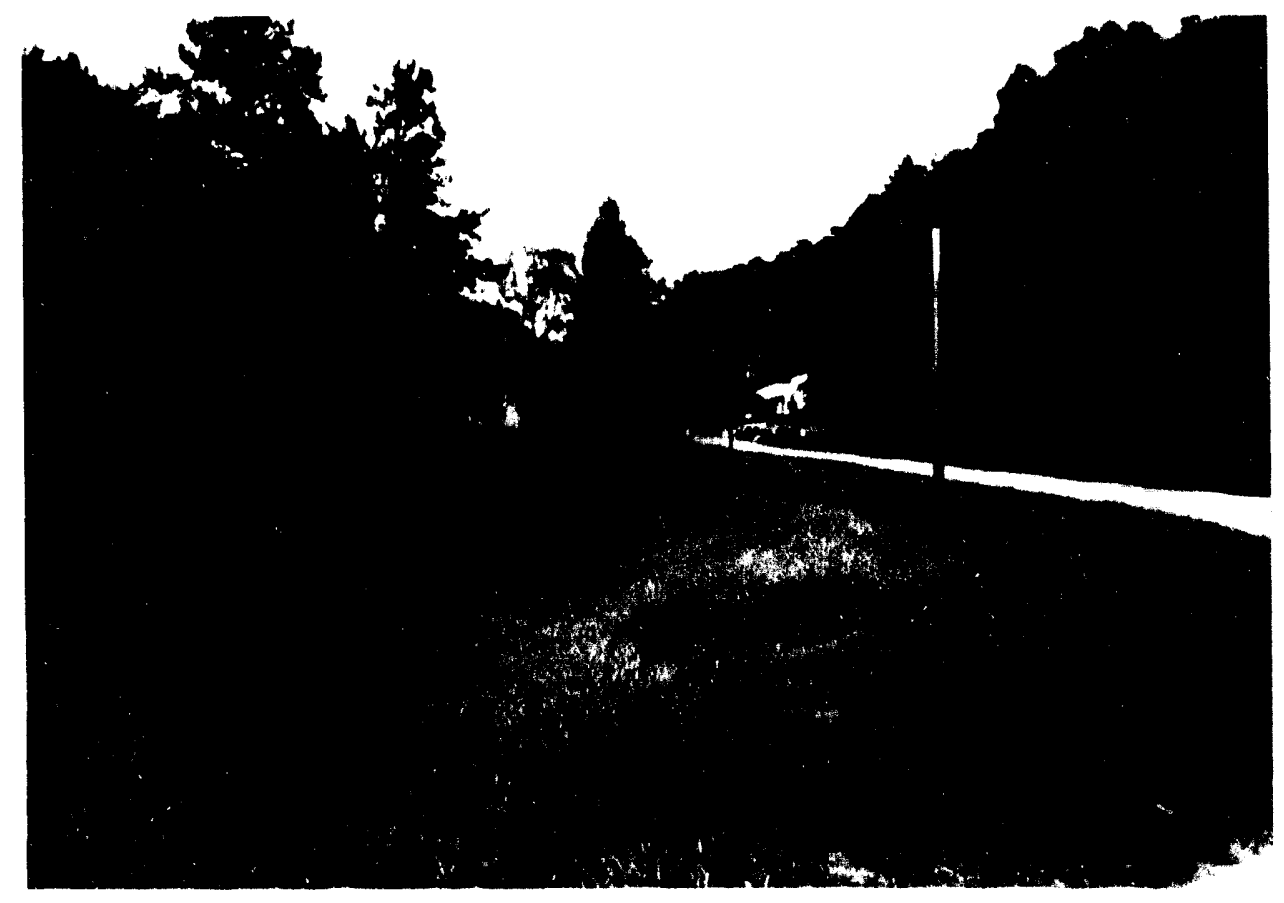

Plate 8. View of Dosimetry Applications Research Facility, which is located in a restricted valley. 


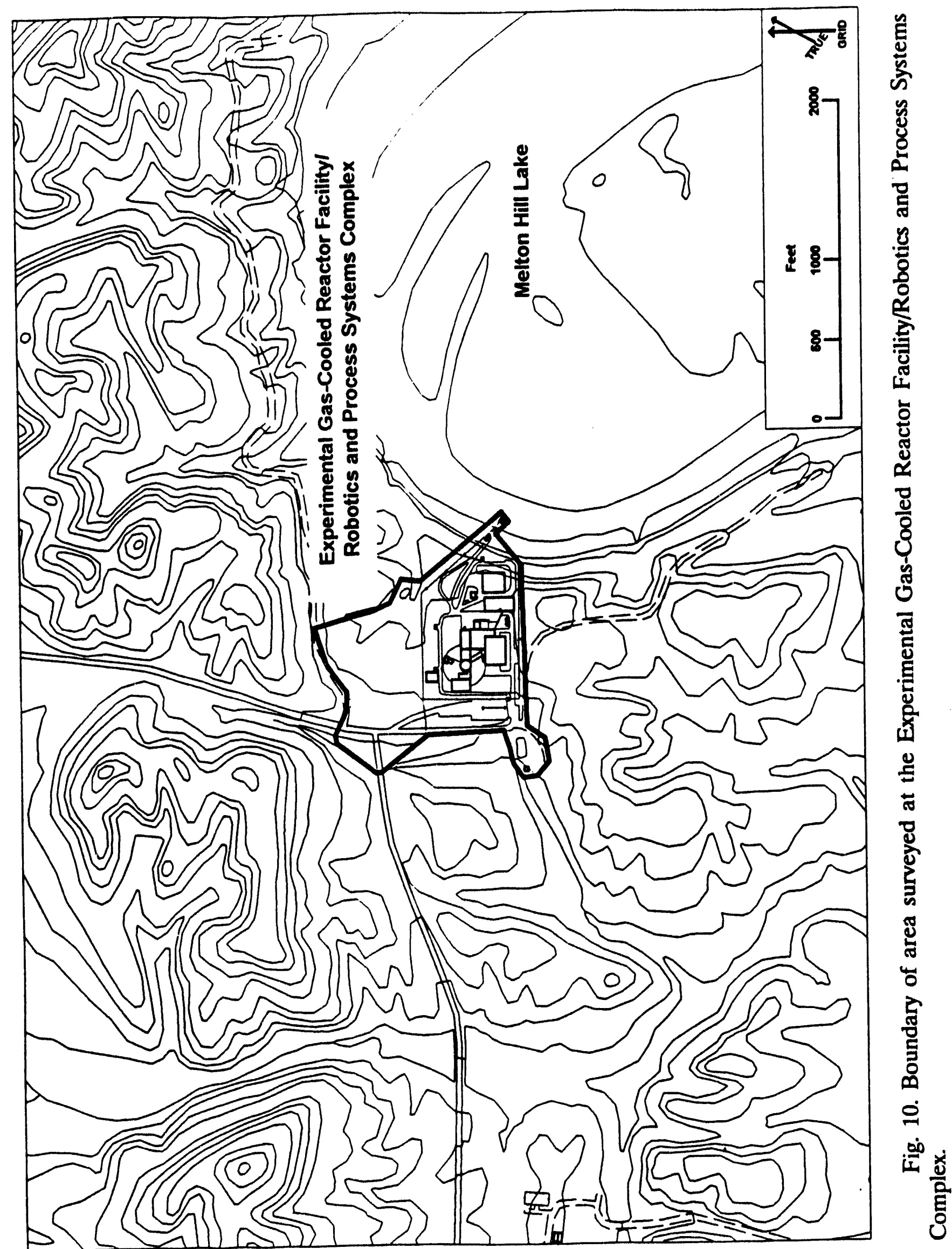




\section{HOMOGENEOUS REACTOR EXPERIMENT FACILITY}

The HRE is located south of Melton Valley Drive and approximately 2500 feet south of the ORNL main facilities complex (Fig. 11). The tract contains approximately 2 acres and, like the ARE/MSRE to the east, has been totally disturbed. Records indicate that several below-grade tanks are located on the tract.

Based on the observed conditions, no additional archaeological investigations are recommended for the tract.

\section{KATY'S KITCHEN}

Katy's Kitchen is located northeast of ORNL main facilities complex (Fig. 12). Katy's Kitchen was originally used as storage facility for enriched uranium which had been processed at Y-12. The facility was constructed in 1948 and was disguised as a barn and silo (Plate 9). The silo was concrete and sheathed in wood and functioned as a guard tower. The hillside was excavated and the facility constructed on the graded section.

The area of the reconnaissance included approximately 3 acres within the circle created by a paved single-lane road. Beyond the laboratory facility, the tract was primarily slope under hardwood cover. A pedestrian reconnaissance of the wooded section revealed deflated soils with heavy chert gravel content. Several areas of prior disturbance included graded areas and power line right-of-ways.

No cultural material was observed on the wooded slopes. Based on the findings, no additional archaeological investigations are warranted for the tract.

\section{GLOBAL CHANGE FIELD RESEARCH FACILITY}

The Global Change Field Research Facility (0800 Area) occupies approximately 6 acres of recontoured field (Fig. 13). The terrain is moderately level but contains several man-made berms with open-topped chambers where plants are raised for experiments (Plate 10). These same areas contain underground utilities servicing the chambers.

Several parking areas, a number of portable buildings, and several Butler-type buildings occupy the tract. The south two-thirds of the tract is currently under maintained grass, while the backslope, or northern one-third of the tract, is under successional growth. 


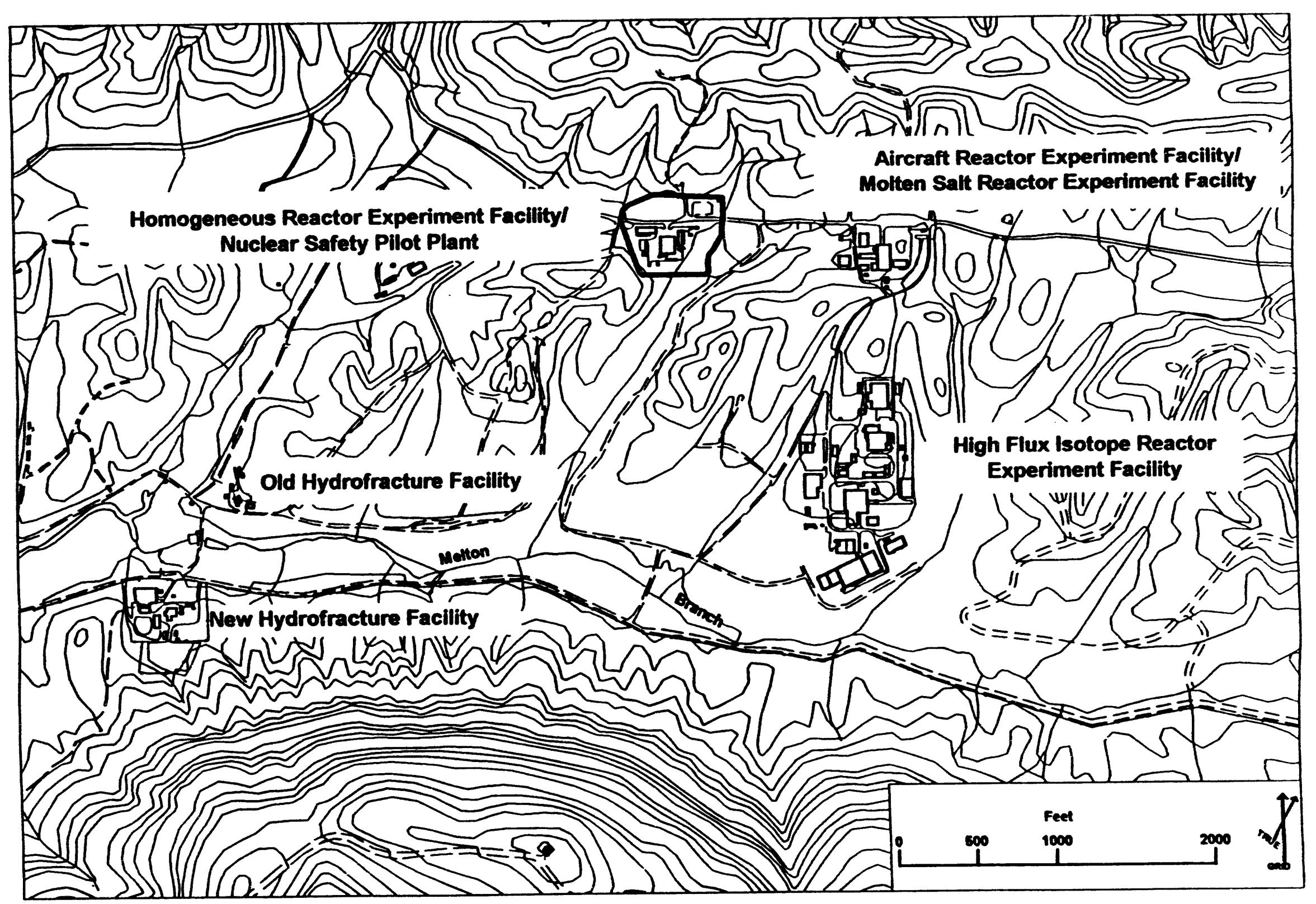

Fig. 11. Boundary of area surveyed at the Homogeneous Reactor Experiment Facility. 
33

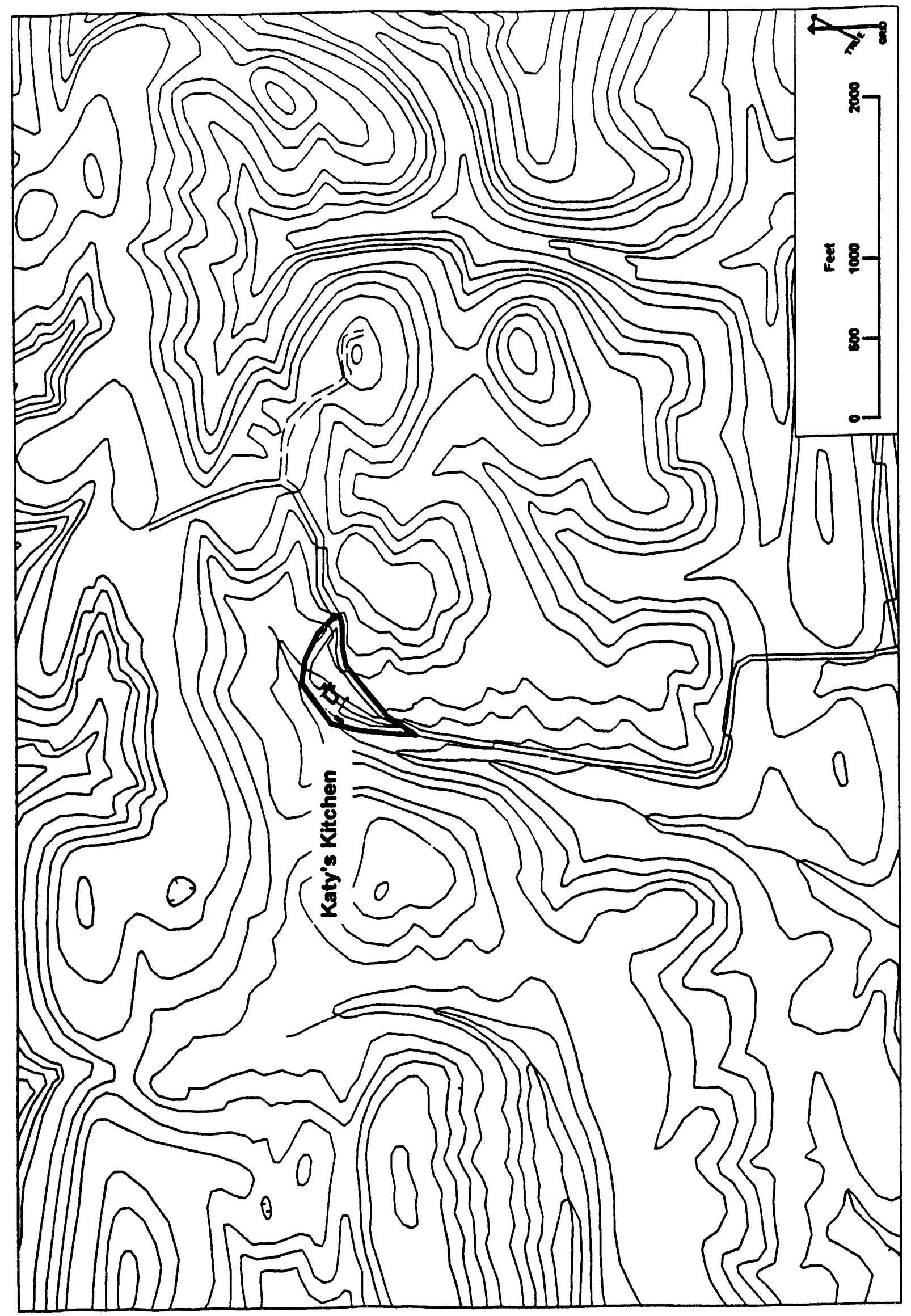

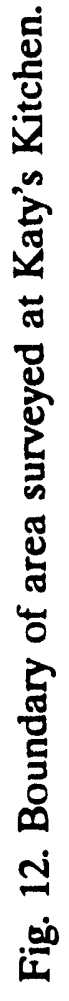




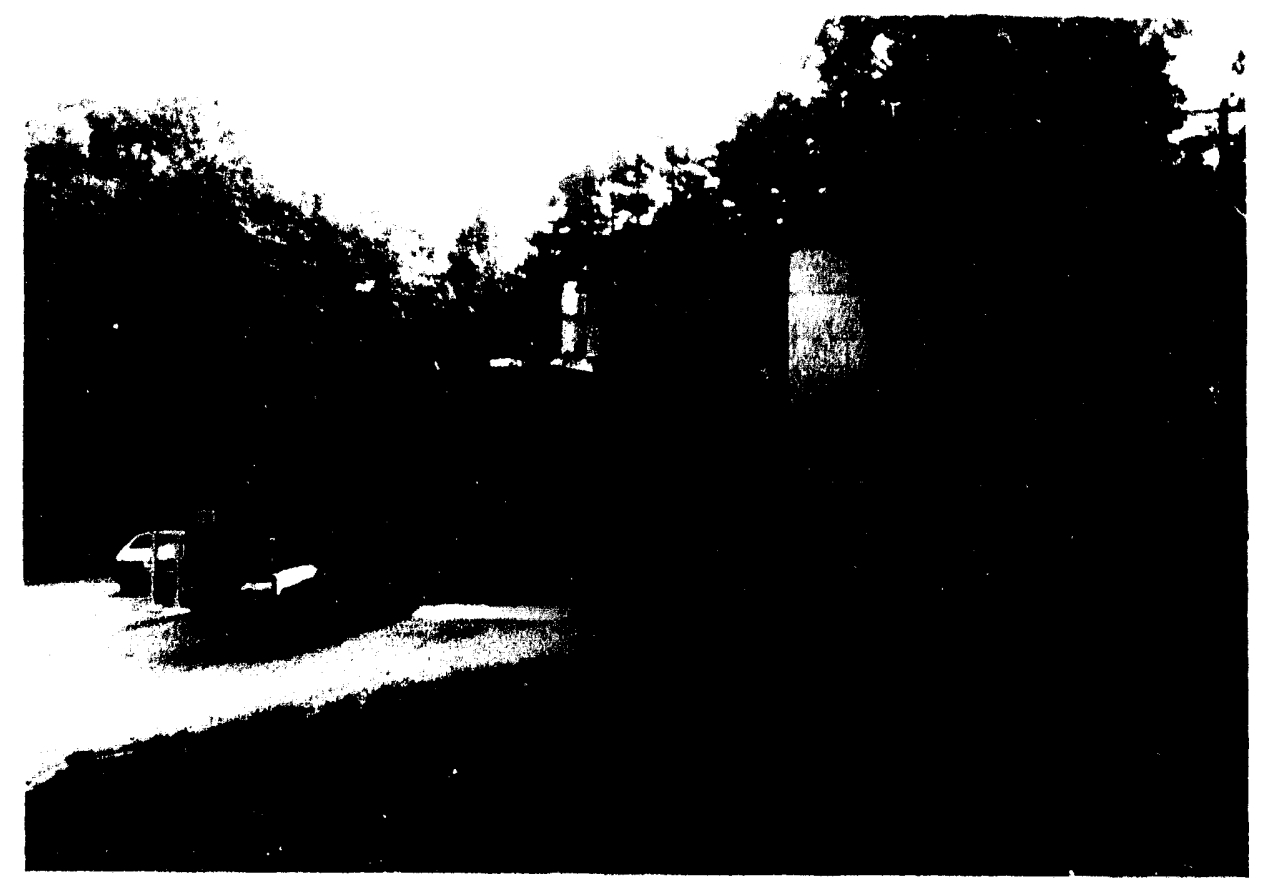

Plate 9. View of Katy's Kitchen, looking north. 


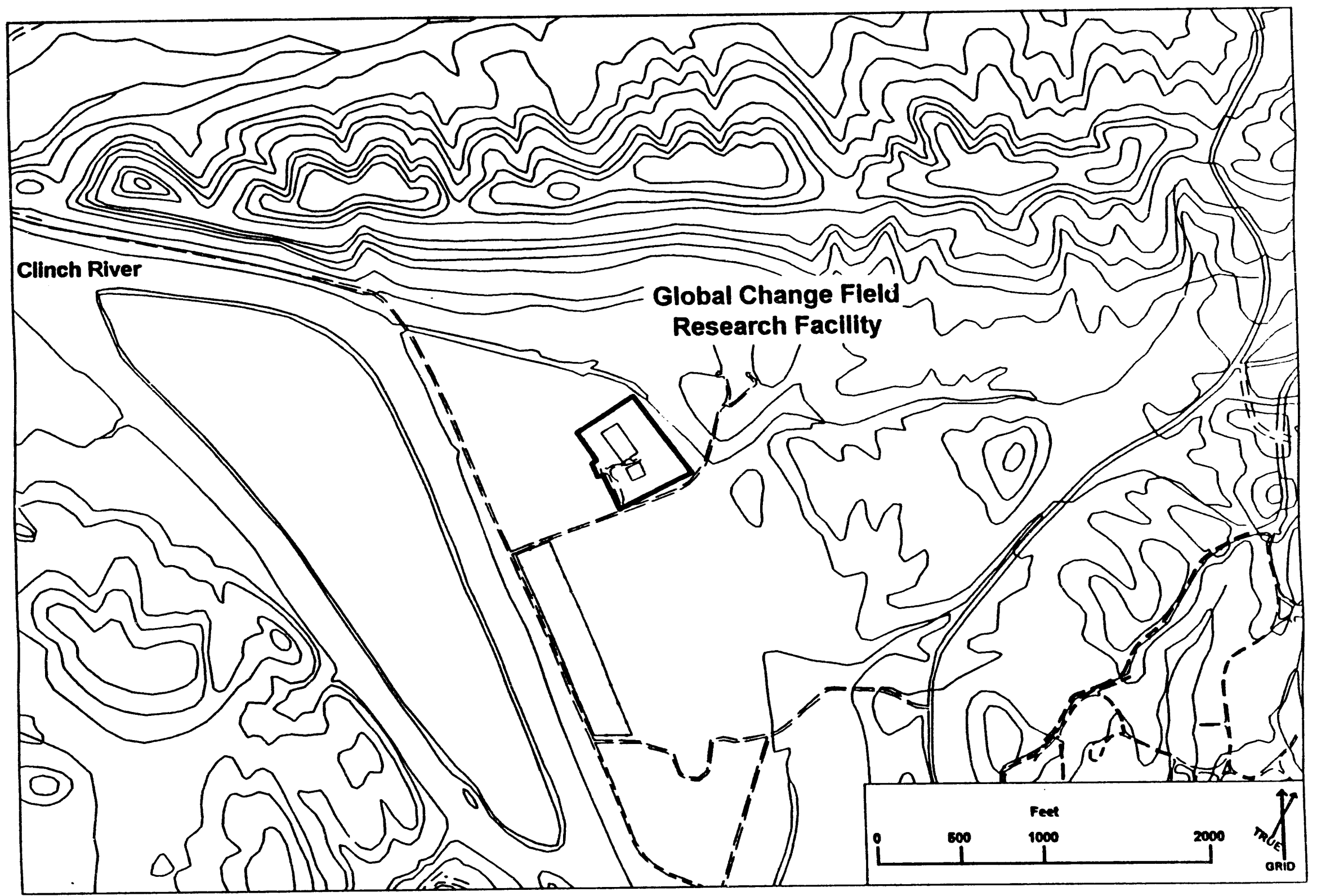

Fig. 13. Boundary of area surveyed at the Global Change Field Research Facility. 


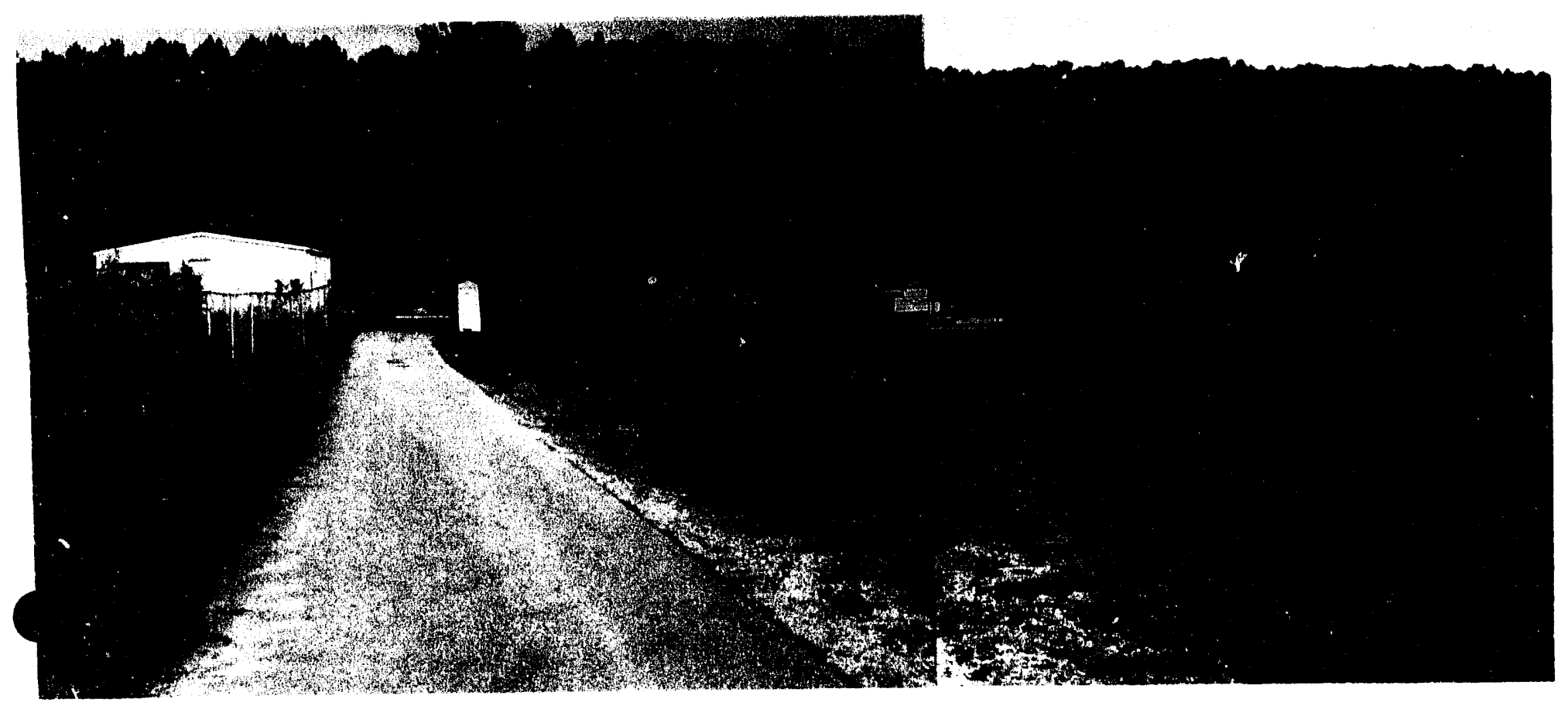

Plate 10. Panoramic view of the Global Change Field Research Facility. 
The location of the Global Change Field Research Facility, on the back of the Clinch River floodplain, was shovel tested on areas that, from the surface, appeared not to have been disturbed. Eight $40 \times 40 \mathrm{~cm}$ shovel tests were placed primarily on the south portion of the tract and in the vicinity of the open-topped chambers.

The shovel tests revealed varying degrees of disturbance from gravel and clay on the surface to silt loam/clay contact at $17 \mathrm{~cm}$. Two of the test units contained a yellowish brown (10YR5/4) silt loam to a depth of $17 \mathrm{~cm}$. This horizon broke immediately to a yellowish brown (10YR5/6) clay. No cultural material was observed in the test units or in the soil exposures present in the open-topped chambers. No further archaeological investigations are warranted for the tract.

\section{CONCLUSIONS}

Based upon the reconnaissance, a search of the site files at the Tennessee Division of Archaeology and a search of the National Register of Historic Places, the future development of areas within the ORNL main facilities complex and support areas discussed in this report will have no effect on any archaeological sites included in or eligible for inclusion in the National Register of Historic Places pursuant to 36 CFR 60.4.

The reconnaissance of the selected portions of the ORNL main facilities complex and support areas revealed areas that have undergone extensive modifications from earthmoving, construction of buildings, and waste disposal. Map evidence and photographs document, to some degree, the amount of change that some landforms have undergone during the last 50 years. This is especially true in the vicinity of the ORNL main facilities complex and the WAG areas. It is unlikely that archaeological sites would have survived intact in those areas. However, should archaeological material be unearthed during construction or drilling activities, activities in the vicinity of the find should cease, and the appropriate personnel should be notified.

Construction in the vicinity of the New Bethel Baptist Church and Cemetery should allow sufficient buffer to avoid direct and visual impact to the property. The determination of sufficient buffer area, either distance or vegetative, should be coordinated with the Tennessee Historical Commission, Office of the State Historic Preservation Officer.

The contractors should be made aware of the present Tennessee burial law (attached) which protects both marked and unmarked, historic and prehistoric interments. In the event that human skeletal material is unearthed during construction activities, construction in the vicinity should cease and the Tennessee Division of Archaeology should be notified. 


\section{REFERENCES CITED}

Department of Energy

1983 Resource Management Plan for the Oak Ridge Reservation: Appendix B: Archaeological Considerations.

DuVall, Glyn D.

1991a An Archaeological Reconnaissance of Two Borrow Areas at the HPRR-DOSAR and Tower Shielding Sites on the Oak Ridge Reservation, Anderson and Roane Counties, Tennessee. Prepared for Martin Marietta Energy Systems, Inc., Oak Ridge.

1991b An Archaeological Reconnaissance of the Melton Valley Liquid Low Level Waste Collection and 1991a An Archaeological Reconnaissance of the Neutron Source Project on the Oak Ridge Reservation, Anderson and Roane Counties, Tennessee. Prepared for Martin Marietta Energy Systems, Inc., Oak Ridge. Transfer System Upgrade on the Oak Ridge Reservation, Roane County, Tennessee. Prepared for Martin Marietta Energy Systems, Inc., Oak Ridge.

1991c An Archaeological Reconnaissance of the Valley Recontour Site on the Oak Ridge Reservation, Roane County, Tennessee. Prepared for Martin Marietta Energy Systems, Inc., Oak Ridge.

1992a An Archaeological Reconnaissance of the Solid Waste Storage Area (SWSA 7) at the Oak Ridge National Laboratory, Oak Ridge Reservation, Tennessee. Prepared for Martin Marietta Energy Systems, Inc., Oak Ridge.

1992b An Archaeological Reconnaissance of the Remote Handled Transuranic Waste Storage Area Within the ORNL Complex, Oak Ridge Reservation, Tennessee. Prepared for Martin Marietta Energy Systems, Inc., Oak Ridge.

1992c An Archaeological Reconnaissance of the Melton Valley Recontour Site, Oak Ridge Reservation. Tennessee. Prepared for Martin Marietta Energy Systems, Inc., Oak Ridge.

1992d An Archaeological Reconnaissance of the M.K. Ferguson Lay-Down Area/West End Treatment Facility and Tank Farm on the Y-12 Complex, Oak Ridge Reservation, Tennessee. Prepared for Martin Marietta Energy Systems, Inc., Oak Ridge.

1992e An Archaeological Reconnaissance of the Waste Grouping (WAG 2) Project at the Oak Ridge National Laboratory, Anderson and Roane Counties, Tennessee. Prepared for Martin Marietta Energy Systems, Inc., Oak Ridge. 
1992f An Archaeological Reconnaissance of the Liquid Low-level Waste Solidification (LWSR) Retrievable Cask Interim Storage Facility at the Oak Ridge National Laboratory, Anderson and Roane Counties, Tennessee. Prepared for Martin Marietta Energy Systems, Inc. Oak Ridge.

1992g An Archaeological Reconnaissance of the Proposed Radio Repeater Facility, Oak Ridge Reservation, Anderson and Roane Counties, Tennessee. Prepared for Martin Marietta Energy Systems, Inc., Oak Ridge.

1992h An Archaeological Reconnaissance of the East End Monitoring Station, Oak Ridge Reservation, Anderson and Roane Counties, Tennessee. Prepared for Martin Marietta Energy Systems, Inc., Oak Ridge.

1992i An Archaeological Reconnaissance of the Proposed Y-12 Plant Chestnut Ridge Access Road, Oak Ridge Reservation, Anderson and Roane Counties, Tennessee. Prepared for Martin Marietta Energy Systems, Inc., Oak Ridge.

1992j An Archaeological Reconnaissance of the Y-12 Plant Drilling Staging Area, Oak Ridge Reservation, Anderson and Roane Counties, Tennessee. Prepared for Martin Marietta Energy Systems, Inc., Oak Ridge.

1992k An Archaeological Reconnaissance of a 14 Mile Section of the East Fork Poplar Creek for the Environmental Restoration Project, Anderson and Roane Counties, Tennessee. Prepared for U.S. Army Corps of Engineers, Nashville District.

1993 An Archaeological Reconnaissance of the Radiochemical Engineering Development (REDC) Facility, Oak Ridge Reservation, Anderson and Roane Counties, Tennessee. Prepared for Martin Marietta Energy Systems, Inc., Oak Ridge.

1993a An Archaeological Reconnaissance of the Proposed Hydrofracture Facility Pipeline, Oak Ridge Reservation, Anderson and Roane Counties, Tennessee. Prepared for Martin Marietta Energy Systems, Inc., Oak Ridge.

1993b An Archaeological and Historical Reconnaissance of the Proposed Office Building, 1500 Area, Oak Ridge Reservation, Anderson and Roane Counties, Tennessee. Prepared for Martin Marietta Energy Systems, Inc., Oak Ridge.

1993c An Archaeological and Historical Reconnaissance of the Proposed Waste Management Operation Health and Hygiene Support Facility, Oak Ridge Reservation, Anderson and Roane Counties, Tennessee. Prepared for Martin Marietta Energy Systems, Inc., Oak Ridge. 
1993d An Archaeological and Historical Reconnaissance of the Proposed Tennessee Valley Authority Transmission Line Relocation, Oak Ridge Reservation, Anderson and Roane Counties, Tennessee. Prepared for Martin Marietta Energy Systems, Inc., Oak Ridge.

1993e An Archaeological Reconnaissance of the Proposed Environmental Safety and Health Compliance and Training Building (ESHCTB), Oak Ridge Reservation, Anderson and Roane Counties, Tennessee. Prepared for Martin Marietta Energy Systems, Inc., Oak Ridge.

1993f An Archaeological and Historical Reconnaissance of the Proposed Center for Biological Sciences and Other Planned Facilities, Inc., Oak Ridge Reservation, Anderson and Roane Counties, Tennessee. Prepared for Martin Marietta Energy Systems, Inc., Oak Ridge.

Faulkner, Charles $\mathrm{H}$.

1988 Archaeological Investigations of the Jenkins House Site (40Re188) and the Jones House Site (40Re189), Copper Ridge, Oak Ridge Reservation, Roane County, Tennessee.

Fenneman, Nevin M.

1983 Physiography of Eastern United States. McGraw-Hill, New York.

Fielder, George F., Jr.

1974 Archaeological Survey With Emphasis on Prehistoric Sites of the Oak Ridge Reservation, Oak Ridge, Tennessee. Oak Ridge National Laboratory, Oak Ridge.

Fielder, George F., Jr., Steven R. Ahler and Ben Barrington

1977 Historic Sites Reconnaissance of the Oak Ridge Reservation, Oak Ridge, Tennessee.

Oak Ridge National Laboratory, Oak Ridge.

GAI Consultants, Inc.

1981 Environmental Research and Technology, Inc. Report on a Cultural resources Survey and Evaluation of the Tennessee Synfuels Associates Site, Oak Ridge Reservation, Roane County, Tennessee.

Hubbard, E.H., et al.

1956 Soil Survey of Sevier County, Tennessee. USDA, Soil Conservation Service, Washington, D.C.

Koeppe, Clarence E. and George C. DeLong

1958 Weather and Climate. McGraw-Hill Book Company, New York. 
McNutt, Charles and F.W. Fisher

1960 Archaeological Investigations in the Upper Melton Hill Reservoir, Anderson County, Tennessee. The University of Tennessee, Department of Anthropology, Knoxville.

McNutt, Charles and J. Bennett Graham

1961 Archaeological Investigations in the Lower Melton Hill Reservoir, Anderson, Knox, Loudon, and Roane Counties, Tennessee. The University of Tennessee, Department of Anthropology, Knoxville.

Nash, Charles H.

1941 Field Notes and Survey Records, Watts Bar Reservoir Survey. On file Frank H. McClung Museum, Knoxville.

Schroedl, Gerald F.

1972 Archaeological Reconnaissance and Test Excavations in the Clinch River Liquid Metal Breeder Reactor Plant Site Area. Submitted to the Tennessee Valley Authority. Prepared by the University of Tennessee, Department of Anthropology, Knoxville.

1974 Historic Sites Reconnaissance in the Clinch River Liquid Metal Breeder Reactor Plant Site. Submitted to the Tennessee Valley Authority. Prepared by the University of Tennessee, Department of Anthropology, Knoxville.

Tennessee Valley Authority

1942 Kingston Demolition Range Map.

Thomas, Cyrus

1894 Report on the Mound Explorations of the Bureau of American Ethnology. In Twelth Annual Report of the Bureau of American Ethnology, Washington, D.C.

Webb, William S.

1938 An Archaeological Survey of the Norris Basin in Eastern Tennessee, Bulletin 118, Bureau of American Ethnology, Washington, D.C. 
ATTACHMENT: TENNESSEE BURIAL LAW 


\section{TENNESSEE DEPARTMENT OF CONSEIRATION \\ DIVISION OF ARCHAEOLOGY}

\section{Memorandum}

'lo: Concerned parties

From: $\quad$ Nick Fielder, State Archaeologist

Subject: New cemetery laws

Dale: $\quad$ March 27, 1990

'I'he 1989 legislature changed the entire criminal code to reduce redundancy and to make sentences more uniform. The changes went into effect on November 1, 1989. All of the previous laws were repealed.

All of the previous sections of the criminal code which dealt with cemeleries and grave robbing were condensed into two sections--TCA 39-17-311 and 3917-312. 311 is a condensation of the cemetery vandalism laws and 312 rewriles the grave robbing and dead bodies laws. The full text is given below.

'Ihe section of the code which permits cemetery relocation-- Termination of use of land as cemetery [TCA 46-4-101-104] is not part of the criminal code and was not changed.

\section{9-17-311. Desecration of a Venerated Object}

(a) A person commits an offense who intentionally desecrates:

(1) A place of worship or burial; or

(2) A state or national llag.

(b) A violation of this section is a Class A misdemeanor.[Acts 1989, ch 591,1].

[Class A misdemeanur is imprisonment for not more than 11mo-29days and/or a fine not to exceed $\$ 2,500$ ] [Acts 1989, ch 591,6]

\section{9-17-312. Abuse of corpse}

(a) A person commits an offense who, without legal privilege, knowingly:

(1) Physically mistreats a corpse in a manner offensive to the sensibilities of an ordinary person;

(2) Disinters a corpse that has been buried or otherwise interred; or

(3) Disposes of a corpse in a manner known to be in violation of law.

(b) A violation of this section is a Class $\mathrm{E}$ felony. [Acts 1989, ch. 591,1]

[Class $\mathrm{E}$ felony is imprisonment of not less than 1 year nor more than 6 years. In addition the jury may assess a fine not to exceed $\$ 3,000$. A corporation may be fined up to $\$ 50,000$ for a Class E felony] 

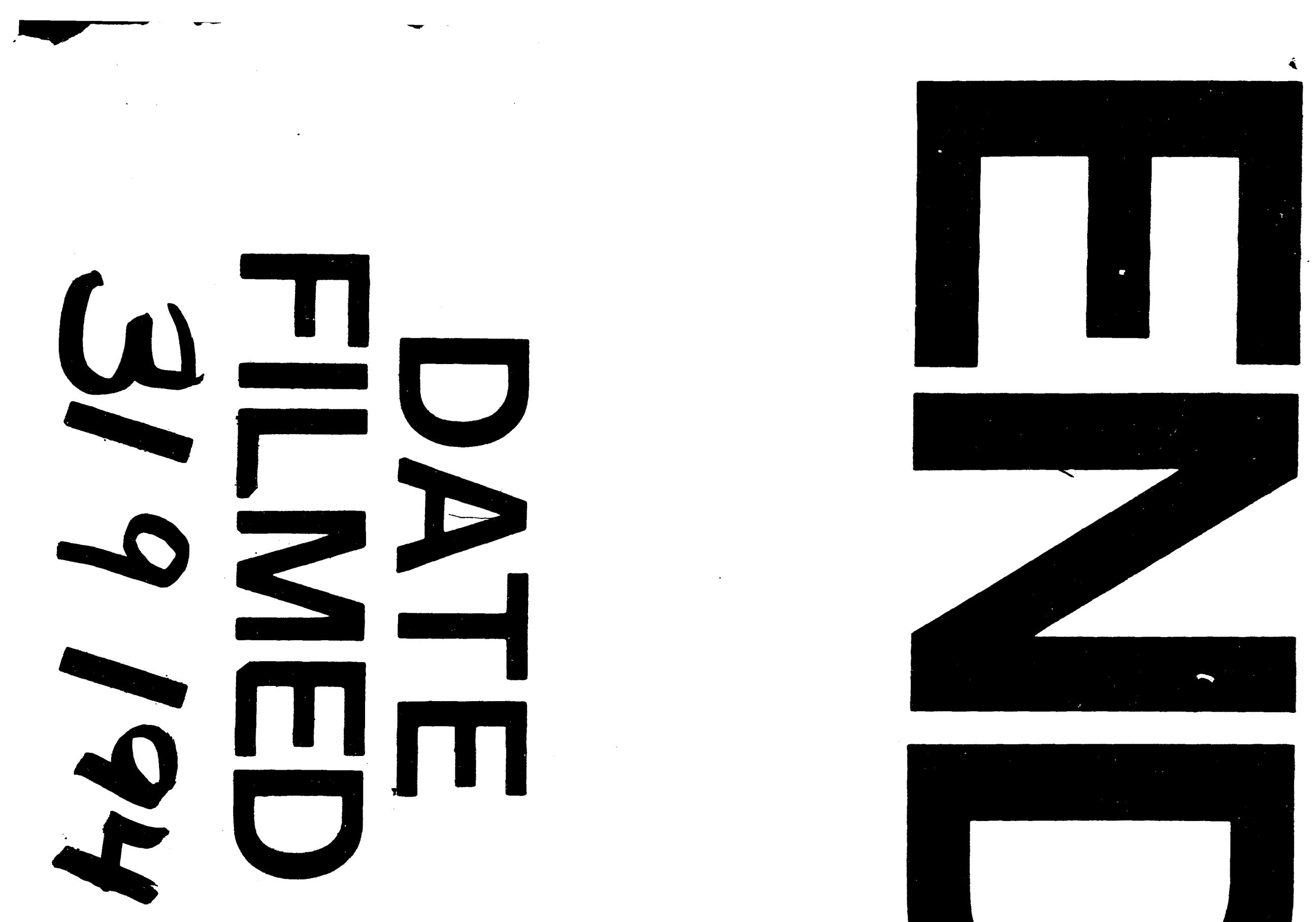

7
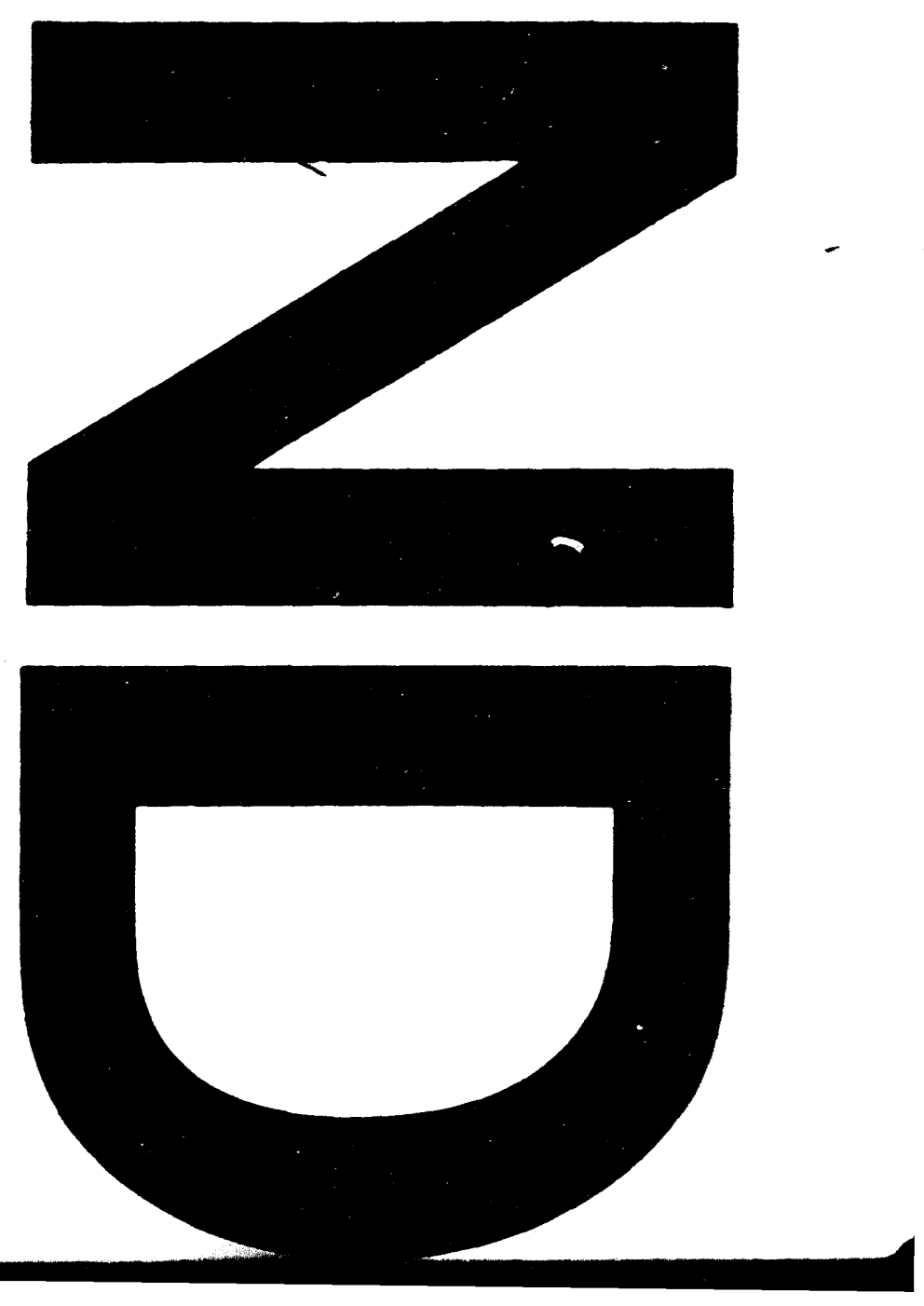


$$
\longrightarrow
$$

